\title{
Do Financial Conglomerates Create or Destroy Economic Value?
}

\author{
Markus M. Schmid and Ingo Walter*
}

This version: 7 September 2006

\begin{abstract}
This paper attempts to ascertain whether or not functional diversification is valueenhancing or value-destroying in the financial services sector. Based on a U.S. dataset comprising approximately 4060 observations covering the period 1985-2004, we report a substantial and persistent conglomerate discount among financial intermediaries. Our results suggest that it is diversification that causes the discount, and not that troubled firms diversify into other more promising areas. We also investigate the geographic dimension of diversification as well as the interaction between geographic scope and functional diversification and find that the value-destruction associated with functional diversification is not apparent in geographic diversification. A further finding is that there is a significant premium for the very largest of our sample firms (with total assets above 100bn USD) indicating that there are "too big to fail" guarantees for very large financial conglomerates.
\end{abstract}

Keywords: Diversification; Focus; Organizational structure; Financial sector; Firm valuation

JEL Classification: G20, G32, G34

\footnotetext{
* Schmid, markus-max.schmid@unibas.ch, Department of Finance, University of Basel, CH-4051 Basel, Switzerland, Phone: +41 6126733 10; Walter, iwalter@stern.nyu.edu, Stern School of Business, New York University, New York, NY10012, USA, Phone: 00121299807 07. We are grateful to Yakov Amihud, Stephen Brown, William Greene, Alexander Ljungqvist, Anthony Saunders, Roy Smith, Lawrence White, and seminar participants at the University of Basel for helpful comments. Special thanks are due to Daniel Hoechle for assistance with the data. Parts of this research were undertaken while Schmid was a visiting scholar at the Stern School of Business, New York. We acknowledge financial support of the Freiwillige Akademische Gesellschaft (FAG), the Swiss National Science Foundation (SNF), and ECOSCIENTIA foundation. All errors are our own.
} 


\section{Introduction}

This paper attempts to ascertain whether or not diversification (revenue and cost economies of scope) is value-enhancing or value-destroying in the financial services sector. The degree of diversification can change either as a financial services firm divests or acquires assets, or as it redirects its business activity into new business segments. Additionally, its portfolio of activities can shift over time due to divergent growth rates in the existing business segments and can assume more or less diverse geographic patterns.

Recent years have seen a burgeoning of mergers and acquisitions in the financial services sector. Of approximately 350,000 M\&A transactions in all industries valued at \$24.6 trillion during 1985-2005 worldwide, approximately 124,000 transactions valued at \$10.1 trillion (41 percent by value) involved the financial services industry - defined as commercial banking, investment banking, insurance, asset management, and financial infrastructure services (clearance, settlement, payments, custody, etc.). ${ }^{1}$ These transactions presumably had as their principal objective increasing the value of the firms involved through some combination of revenue enhancement, improved operating efficiency, or risk reduction. All of the transactions either increased the firm's market share, defined functionally or geographically, or diversified its operations across financial functions or geographies (or both). Of the aforementioned financial-sector transactions, about $20 \%$ by value were “cross-market," involving at least two areas of financial services activity, and about 7\% were “cross-border" involving more than one country. At the extreme, both financial conglomerates and global financial firms have emerged as important participants in the market for financial services.

\section{General Arguments for Diversification in Financial Intermediation}

Various arguments have been made in favor of diversification in marking the optimum institutional boundaries of financial services firms: ${ }^{2}$

\footnotetext{
${ }^{1}$ The data cover only transactions valued at $\$ 100$ million or more. Source: Thomson Financial Securities Data Corporation.

${ }^{2}$ For a review, see Walter (2004), Chapter 3.
} 
- Cost economies of scope - sharing of joint costs such as IT platforms across a diversified range of activity lines leads to higher levels of operating efficiency ( $\mathrm{x}$ efficiency).

- Revenue economies of scope - cross-selling multiple financial services to clients, resulting in reduced client information and/or transactions costs, and consequently higher prices and/or transaction volumes for the intermediary.

- Internal capital market efficiency exceeds external capital market efficiency due to better coordination across highly specialized activity lines, better monitoring and control of capital expenditures, sharing of managerial best-practices, etc., leading to better performance compared with specialized financial firms.

- Exploitation of information asymmetries, with financial services firms held to be more opaque to investors than non-financial firms and management of multifunctional financial firms able to make profitable use of private information.

- Internal labor market efficiency exceeds external labor market efficiency in an industry where activity-specific know-how is largely embedded in human capital, so private information on staff performance allows human capital to be allocated optimally across functions.

- More efficient use of proprietary client-related information in revenue generation, pricing, and risk assessment - e.g. using the less capital-intensive Advanced Management Approach (AMA) as opposed to the standardized approach under the Basle 2 capital adequacy standards.

- Reduced bankruptcy risk due to less than perfectly correlated revenue streams across functions, resulting in improved debt ratings, higher debt capacity, higher share prices and lower WACC than is true for more specialized financial intermediaries.

- Incremental financing capacity in financial conglomerates, allowing investments in high-NPV projects that might otherwise have been foregone.

- Increased market power attributable to tying credit facilities to fee-earning mandates in mergers and acquisitions, corporate restructurings, capital-raising and similar activities. 
- Lower tax burdens (depending on applicable tax codes) as a result of intra-firm transactions that are more tax-efficient than transactions among independent financial services firms. ${ }^{3}$

- Too-big-to-fail guarantees, provided by the public at zero or below-market cost through the central bank or public guarantee agency, which supports the creditworthiness of the banking unit of a financial conglomerate and by extension the entire financial firm.

\section{General Arguments Against Diversification in Financial Intermediation}

The principal arguments against diversification in financial intermediaries include the following:

- Cross-subsidization across business lines, and hence inefficient allocation of capital and reduced performance incentives in profitable businesses.

- Overinvestment in low-NPV projects attributable to excess free cash-flow and unused borrowing capacity, as well as non-materiality of individual capital allocation errors in relation to firm's overall market value.

- Conflicts between central and divisional management in the presence of internal information asymmetries - as well as interdivisional conflicts regarding compensation systems and attribution of revenue, cost and risk.

- Excessive merger premiums paid in the process of activity-diversification and incremental costs associated with merger integration.

- Inability of investors to obtain "clean” exposure to specific areas of financial services activity, and hence to construct efficient portfolios based on their asset allocation objectives.

- Conflicts of interest among clients and activity areas of financial conglomerates that create incremental reputation risk, therefore higher debt costs and a lower share price.

\footnotetext{
${ }^{3}$ Santomero (1995) argues that if the tax argument holds, American firms would be less interested in reducing the volatility of their earnings as a result of lower marginal U.S. corporate tax rates, but could find no evidence to support his contention.
} 
Whether the arguments for or against diversification and financial conglomerates dominate is a key issue in defining the strategies of financial intermediaries and the evolving architecture of national and global financial systems.

We use a large U.S. dataset comprising approximately 4,060 observations and covering the period 1985-2004 to ascertain whether the benefits associated with functional diversification outweigh the costs - whether functional diversification is valueenhancing or value-destroying in the financial services sector. Our results show a substantial and persistent conglomerate discount among financial intermediaries. Moreover, our results suggest that it is diversification that causes the discount, and not that troubled firms diversify into other more promising areas. We use Heckman's (1979) two-step procedure to control for the endogeneity of the diversification decision. Additionally, we investigate whether firms that diversify are already trading at a discount prior to the diversification, or whether their value decreases as a result of the diversification, by testing the relationship between changes in the degree of diversification and firm value. We also investigate the geographic dimension of diversification and find that the value-destruction associated with functional diversification is not apparent in geographic diversification. In contrast, conditional on being functionally diversified, we provide evidence that geographical diversification is related to a valuation premium. We also test whether there is evidence on the existence of so-called "too big to fail" guarantees. In fact, we find no conglomerate discount and a significant premium for the very largest of our sample firms (with total assets above $\$ 100 \mathrm{bn}$ ) indicating that the financial markets believe that there are "too big to fail" guarantees for very large financial conglomerates.

The remainder of the paper is organized as follows. Section II provides a literature review. Section III outlines the sources of data and sample selection and specifies the independent and dependent variables - measures of diversification and excess value, respectively. Sections IV and V present the descriptive statistics from univariate analysis and the results from multivariate regression analysis. Section VI considers the excess value impact of changes in diversification. Section VII examines whether geographic extension of financial firms' operations appear to create or destroy economic value. Section VIII presents the conclusions. 


\section{Literature Review}

This paper attempts to contribute to the empirical literature on corporate finance and industrial organization related to financial intermediaries, which so far has been limited by the lack of comparability of data on key variables (e.g., sales, operating income, etc.) between financial and non-financial firms. ${ }^{4}$ Specifically, the literature on the costs and gains associated with financial conglomerates is very limited, although there is a very large literature on the conglomerate discount for non-financial firms. A number of empirical studies have back-tested the impact of hypothetical combinations of stand-alone firms in different areas of financial intermediation, and have conducted event studies of broadening or focusing merger announcements as well as regulatory changes making possible increased scope.

In an early study, Berger and Humphrey (1992) find that scope economies could lower the costs of a commercial bank by $10 \%$ to $20 \%$, although Saunders and Walter (1994) find negative cost economies of scope among the world's 200 largest banks - as the product range widens, unit-costs appear to rise. Mitchell and Onvural (1995) examine the cost structure of more than 300 banks with assets between $\$ 500$ million and $\$ 100$ billion in 1986 and 1991, and find extremely weak evidence for the existence of economies of scope.

Santomero and Chung (1992) create hypothetical bank holding companies composed of various combinations of banking, insurance, and securities firms to back-test whether activity diversification could reduce risk and therefore promote financial stability. The authors find that bank holding companies that existed from 1985 to 1989 could have reduced their probability of failure had they been permitted to diversify into insurance and securities. Boyd, Graham, and Hewitt (1993) test whether hypothetical mergers between bank holding companies and non-banking financial firms decrease risk. In their sample of data from 1971 to 1987, they find that mergers between bank holding companies and insurance firms could have reduced risk while mergers between bank holding companies and securities firms or real estate firms would have increased risk. Similarly,

\footnotetext{
${ }^{4}$ Nevertheless, $20.5 \%$ of all firms on the Compustat Industrial Annual File were classified as financial firms (SIC 6000-6999) in 1985, the beginning of our sample period. In 2004, the percentage of financial firms (NAICS 520000-529999) had increased to 24.2\%.
} 
Saunders and Walter (1994) carry out a series of simulated mergers between U.S. banks, securities firms and insurance companies in order to test the stability of earnings of the pro-forma "merged" firm as opposed to separate institutions. The findings suggest that there are indeed potential risk-reduction gains from diversification in multi-activity financial services organizations, and that these gains increase with the number of activities undertaken. The main risk-reduction gains appear to arise from combining commercial banking with insurance activities, rather than with securities activities. In a recent paper focusing on US financial holding companies, Stiroh and Rumble (2006) find that diversification from lending into non-interest activities damages risk-adjusted performance. Robust statistical results show that any scope-related gains are more than offset by the higher volatility of these activities.

With respect to U.S. legislation making possible the creation of multi-functional financial intermediaries, Lown, Osler, Strahan, and Sufi (2000) find that both commercial and investment bank stocks rose on announcement by President Clinton on October 22, 1999 that passage of the Gramm-Leach-Bliley Act was imminent. This finding is supported by Yu (2001) in an event-study of stock price reactions of U.S. financial services firms to the 1999 Act, concluding that the market reacted most favorably in the case of large securities firms, large insurance companies, and bank holding companies already engaged in some securities businesses (those with so-called "Section 20 subsidiaries" allowing limited investment banking activities) and suggesting that the market expected gains from product diversification possibly arising from cross-product synergies or perhaps extension of "too big to fail” guarantees.

Evidence from merger data includes Houston, James and Ryngaert (1999), who find that in-market (concentrating) mergers tend to create value upon announcement based on the U.S. financial services M\&A deal-flow. Targets of in-market mergers gain and acquirers do not lose. In-market takeovers are expected to cut costs faster and more dramatically than market-extending acquisitions. Similarly, DeLong (2001a) finds that the market reacts positively to bank mergers that focus activities and geography, concluding that efficient acquirers tend to improve the efficiency of the merged entity more than other acquirers. 
With respect to the geographic dimension of diversification, Cornett and Tehranian (1992) find that improvement is greater for bank mergers within U.S. states than between U.S. states, while Cornett, Hovakimian, Palia, and Tehranian (1998) find that mergers of partners headquartered in the same U.S. state earn higher returns than mergers with partners in different U.S. states. Houston and Ryngaert (1994) find that the market rewards financial services mergers where geographic overlap exists between acquirer and target. DeLong (2001b) finds no significant relation between long-term performance of bank mergers and geographic overlap between the two merged entities. Brewer, Jackson, Jagtiani, and Nguyen (2001) find that merger premiums increased by about 35 percent as a result of geographic deregulation, in this case the passage of the 1997 Riegle-Neal act, which eliminated geographic restrictions for U.S. banking operations.

In a study confined largely to the banking industry - comprising 836 banks from 43 different countries - using Tobin's q of financial conglomerates benchmarked against the $\mathrm{q}$ the same firms might have had based on the adjusted $\mathrm{q}$ values of specialized financial firms, Laeven and Levine (2005) find strong evidence of a conglomerate discount which withstands a battery of robustness and sensitivity checks. They conclude that all diversification of bank-based financial services firms is fundamentally value-destroying. The authors attribute (but cannot confirm) this to agency problems associated with financial conglomerate structures, and conclude that their findings definitively negate the existence of scope economies in such firms. However, the authors limit their analysis to banks, do not examine the geographic dimension of diversification and the interaction between geographic and functional diversity, and their results may be subject to survivorship bias. ${ }^{5}$

Empirical studies of the conglomerate discount issue for non-financial firms include Berger and Ofek (1995), who find that diversification among non-financial conglomerates implies a 13-15\% value loss as compared with specialized stand-alone firms during the period 1986-1991. The closer together the activities of diversified firms (in

\footnotetext{
${ }^{5}$ The total of 836 banks in the sample corresponds to the maximum of 836 bank observations in 2002 (the end of their sample period). In particular, the use of Heckman's (1979) self-selection model may have a limited meaning when banks with poor (or at least those with the worst) performance are excluded from the sample. However, Laeven and Levine's results based on Heckman's two-step procedure are consistent with ours. Given its focus on the banking sector, the Laeven and Levine study is largely complementary to the broad-gauge financial-services focus of this study.
} 
terms of 3-digit SIC categories) the less the corresponding value loss. Similarly, Lang and Stulz (1994) find that Tobin's q is negatively related to diversification based on data through the 1980s, regardless of the measure of diversification used. There is also some international evidence on the valuation effect of functional diversification. Lins and Servaes (1999), for example, using the valuation methodology proposed by Berger and Ofek (1995), find similar discounts in Japan and the United Kingdom. ${ }^{6}$ Chen and Ho (2000) report a significant value loss from diversification for a sample of Singapore firms in 1995. Beiner and Schmid (2005) find that a 14-24\% valuation discount is associated with Swiss conglomerates, and that this discount is lower for firms that apply sound governance practices and have large block-holdings by outside investors - although management shareholdings have no effect.

A more recent stream of literature investigates whether it is in fact corporate diversification that causes the discount or whether already discounted firms tend to diversify away from industries experiencing difficulties into more promising industries. For example, Campa and Kedia (2002) use fixed effects regressions, a simultaneous equations framework and Heckman's self-selection model to control for the endogeneity of the diversification decision. Their results indicate that the diversification discount declines substantially and sometimes turns into a premium when the endogeneity of the diversification decision is accounted for. Based on similar econometric techniques, Villalonga (2004) likewise shows that the failure to control for firm characteristics that lead firms to diversify and be discounted may wrongly attribute the discount to diversification instead of the underlying characteristics.

This study is in the tradition of Berger and Ofek (1995) in seeking to determine whether, based on available U.S. data on firms engaged in financial intermediation functions, activity diversification is associated with a share price premium or discount. We extend the analysis by additionally including the geographic dimension of diversification (e.g., see Denis, Denis, and Yost, 2002) and testing some peculiarities associated with diversification such as the existence of "too big to fail" guarantees. We also account for the endogeneity of the diversification decision in our econometric analysis.

\footnotetext{
${ }^{6}$ However, they find no significant diversification discount in Germany. They argue that international differences in corporate governance might affect the impact of diversification on shareholder value.
} 


\section{Sample selection and variables}

\section{A. Sample selection}

The sample consists of all financial firms (SIC 6000-6999 and NAICS 520000529999) from 1985 to 2004, with data reported on both the Compustat Segment and Industrial Annual data files and total assets of at least \$100 million. The data cover the broadly-defined US financial services sector - commercial banks and bank holding companies, insurance companies, asset managers and broker-dealers. We exclude years where more than $50 \%$ of a firm's sales or assets stem from segments outside the financial sector or are classified as investment trusts (SIC 6730-6733 and 6798 and NAICS 525900525990). We also exclude firms that are listed as American Depository Receipts (ADRs). ${ }^{7}$ To examine whether diversification increases or decreases corporate value, we use the excess value measure developed by Berger and Ofek (1995). For a firm to be included in our sample, all data necessary to calculate this excess value measure are required (see description below) leading to a final sample of 664 firms with a total of 4,060 firm-year observations when the excess value measure is based on sales and 652 firms and 3,812 firm-year observations when the excess value measure is based on assets. ${ }^{8}$

During our sample period, the segment reporting changed from SIC to NAICS. Specifically, for the years 1985 to 1989 only SIC codes are available on Compustat's Segments file, from 1990 to 2000 SIC and NAICS codes are available, and from 2001 to 2004 only NAICS codes are available. In general, we use NAICS codes where available (i.e., from 1990 to 2004) and SIC otherwise. To account for possible changes in segment reporting due to the change from SIC to NAICS, we split our sample into two different sub-samples, which are exclusively based on SIC, (from 1985 to 2000), or NAICS (from 1990 to 2004). All our results refer to "case 1", i.e. we use NAICS where available and SIC otherwise. ${ }^{9}$

\footnotetext{
7 This restriction leads to a decrease in sample size of 131 firm-year observations (3.1\%) for the excess value measure based on sales and 100 firm-year observations $(2.6 \%)$ for the excess value measure based on assets. The inclusion of these observations does not materially change any of our results.

${ }^{8}$ Compustat defines sales for financial companies as follows: total current operating revenue plus net pretax profit or loss on securities sold or redeemed minus non-recurring income.

${ }^{9}$ For both sub-samples (SIC: 1985-2000; NAICS: 1990-2004) and also when we use SIC codes where available and NAICS otherwise over the full sample, the results of the univariate as well as the multivariate
} 


\section{B. Measure of Excess Value}

To examine whether diversification increases or decreases corporate value, we use an excess value measure that compares a firm's value to its imputed value if its segments were operated as stand-alone entities (Berger and Ofek, 1995). Each segment of a diversified firm is valued based on the median sales (assets) multipliers for single-segment firms in that industry.

First, we calculate the imputed value for each segment by multiplying the segment's sales (assets) by the median ratio of sales (assets) to market value for singlesegment firms in the same industry. The industry median ratios are based on the narrowest NAICS/SIC grouping that includes at least five single-segment firms with complete data and total assets of at least $\$ 100$ million. ${ }^{10}$ Next, the imputed value of the firm is calculated as the sum of the imputed segment values. This number estimates the value of the firm if all of its segments were operated as stand-alone entities. Finally, excess value is calculated as the log of the ratio of a firm's value to its imputed value. A negative excess value indicates that a firm trades at a discount and a positive excess value implies that the firm trades at a premium.

Some of the segments of diversified firms in our sample have no NAICS or SIC codes assigned by Compustat. In contrast, most have a segment name, usually stated as "corporate and other," "eliminations," "corporate and unallocated," or a similar designation. We do not treat these segments separately, but rather attribute their sales (assets) proportionally to the remaining segments in order to sum to the correct figure for the firm's total sales (assets). Nevertheless, for some of the diversified firms in our sample the sum of all segment sales (assets) as provided by the Compustat Segment file disagrees with the respective firm total values from the Compustat Industrial Annual file. This problem is also noted by Berger and Ofek (1995), and we follow their approach by excluding observations for which the sum of the segment values deviates from the firm's total value by more than $25 \%$. This procedure leads to a reduction in sample size of 243

analysis (Sections IV and V) are very robust. Therefore, we only report the results based on NAICS codes where available (i.e., from 1990 to 2004) and SIC otherwise.

${ }^{10}$ Using sales (and assets) multipliers, the imputed value for $40.4 \%$ of all segments are based on five-digit NAICS (4-digit SIC) codes, $28.4 \%$ on four-digit NAICS (three-digit SIC) codes, $26.8 \%$ on three-digit NAICS (two-digit SIC) codes, and $4.5 \%$ on two-digit NAICS (one-digit SIC) codes. 
(5.1\%) and 158 (3.6\%) observations, respectively, for the sales- and asset-based excess value measure. If the deviation is within $25 \%$, we gross the firm's imputed value up or down by the percentage deviation between the sum of its segments' sales (assets) and total firm sales (assets). Finally, again following Berger and Ofek (1995), we exclude extreme excess values from the analysis - i.e., the actual value is either larger than four times the imputed or less than one fourth of the imputed value - which results in the loss of 428 (9.5\%) and 411 (9.7\%) firm-year observations for sales- and asset-based excess value measures, respectively. This procedure leads to a final sample size of 664 firms with a total of 4,060 firm-year observations for the sales-based excess value measure and 652 firms with a total of 3,812 firm-year observations for the asset-based excess value measure.

Finally, we construct a third alternative excess value measure which is based on both sales and assets. The underlying presumption behind this "hybrid" excess value measure is that in some industries assets-multiples are more meaningful to measure valuation and in other industries sales-multipliers are more meaningful. Specifically, we presume that a lower standard deviation of the multipliers of focused firms in an industry implies a higher precision in measurement and therefore a more meaningful imputed segment value. Hence, we calculate for each segment of a firm the corresponding median sales- and asset-multipliers and use that with the lower scaled standard deviation to calculate the imputed value of a segment (again industry median ratios are based on the narrowest NAICS/SIC grouping that includes at least five single-segment firms with complete data and total assets of at least $\$ 100$ million). To obtain the excess value measure we again calculate the imputed value of the firm as the sum of the imputed segment values. Finally, excess value is calculated as the log of the ratio of a firm's value to its imputed value. $^{11}$

\section{Measures of Diversification}

We use a series of alternative measures of diversification. The first is a dummy variable which is equal to one if a firm reports more than one segment in Compustat's Segments data file. Earlier evidence (e.g., Lang and Stulz, 1994) suggests that firms with

\footnotetext{
${ }^{11}$ We are grateful to Yakov Amihud for suggesting this alternative measure of excess value to us.
} 
two or more segments have a lower firm value than firms with one segment, but that there is no further significant drop in firm value when one moves from firms with $j$ segments to firms with $j+1$ segments, where $j \geq 2$.

To investigate whether this finding is also valid for our sample of financial firms, we alternatively use the number of segments reported by Compustat. Additionally, we use a sales- and asset-based Herfindahl-Hirshman index (HHI) following Lang and Stulz, (1994), Comment and Jarrell (1995), and Denis, Denis and Sarin (1997). These HHIs are computed as the sum of the squares of each segment's sales (assets) as a proportion of total sales (assets) for the firm. For example, if a firm has only one segment, its $\mathrm{HHI}$ is equal to one and if it has 10 segments that each contribute 10 percent of the sales (assets), its $\mathrm{HHI}$ is equal to 0.1. Hence, the HHI decreases as the degree of diversification increases.

Prior research on non-financial firms (e.g., Berger and Ofek, 1995) revealed that only unrelated diversification (i.e., diversification at the two-digit SIC code level) is associated with a significant discount in firm value, and that there is no conglomerate valuation penalty for related diversification (i.e., diversification at the four-digit SIC level). We therefore investigate potential differences in the valuation effects associated with related and unrelated diversification. However, given that all of the focused firms in our sample are exclusively in the financial sector (NAICS 520000-529999 and SIC 6000-6999) and the majority of sales and assets of diversified firms are attributed to the financial sector as well, the distinction between related and unrelated diversification is not directly comparable to that in previous research carried out with respect to non-financial firms.

Specifically, we construct a dummy variable, which has a value of one if a firm reports more than one segment based on three-digit-level NAICS codes (two-digit-level SIC codes) to measure unrelated diversification, and a similar dummy variable, which has a value of one if a firm reports more than one segment based on five-digit-level NAICS codes (four-digit-level SIC codes) to measure related diversification. It is important to bear in mind that diversification takes place almost exclusively within the financial sector. However, 162 firm-year observations (4.0\%) correspond to 49 different diversified firms with at least one segment outside the financial sector. Since in these cases the term "unrelated diversification" becomes comparable to that used in prior research on non-financial 
firms (where firms are often diversified even at the one-digit-level SIC or two-digit-level NAICS code), we additionally construct a dummy variable, which is equal to one if a firm is diversified at the three- (NAICS) or two-digit-level (SIC) and has at least one segment outside the financial sector.

\section{Univariate Analysis}

We begin the univariate analysis by investigating whether diversified and focused firms differ with respect to a number of variables. Table 1 reports the mean and median (as well as tests for differences in means and medians) for all variables used in the study for diversified and focused firms separately. All firms reporting more than one segment are classified as diversified. With one exception (the median of the ratio of intangible to total assets), the differences in means and medians between diversified and focused firms are statistically significant at the $1 \%$ level for all variables. Most important, the three excess value measures are all significantly higher for focused than for diversified financial firms, which provides initial evidence of a diversification discount for financial conglomerates. Moreover, diversified firms are substantially larger (market value, sales, and assets), have higher leverage ratios (which is consistent with Lewellen, 1971), are less profitable (lower return on assets), and exhibit lower book-to-market and q ratios.

Table 2 gives an overview of the number of sample firms for each calendar year, along with the number (and percentage) of focused and diversified firms. Comment and Jarrell (1995) show a steady trend toward greater focus over their sample period from 1979 to 1988 . For example, in 1979, 38.1\% of all firms in their sample reported one segment. In 1988, the percentage increased to $55.7 \%$. Over the same period, the average number of segments reported dropped from 2.53 to 1.94. In a more recent study, Denis, Denis, and Yost (2002) find that the percentage of diversified firms in their sample of non-financial firms decreases from $26.3 \%$ in 1984 to $12.3 \%$ in 1997. The results in Table 2 show that the percentage of diversified firms in our sample decreases steadily from $53.2 \%$ in 1985 to $27.3 \%$ in 1996 and then rises again to $48.9 \%$ in 2004 .

In general, the percentage of diversified firms in our sample of financial firms seems to be somewhat higher as compared to non-financial firms prior to 1997. Unfortu- 
nately, the sample period in other research on non-financial firms usually ends in 1997 or earlier, even for recent studies (e.g., the sample periods in Campa and Kedia (2002), Fauver, Houston, and Naranjo (2004), and Ahn, Denis, and Denis (2006) end in 1996, 1995, and 1997, respectively) and therefore we do not know whether the subsequent increase in the percentage of diversified firms is a general phenomenon or exclusively related to financial firms. Finally, the results in Table 2 show a large jump in the percentage of diversified firms between 1997 and 1998. There are four possible explanations for this jump: 1) A large percentage of sample firms changed the level of diversification in this year (e.g., due to the expectation of US regulatory change or the impact on firm strategies of the merger of Citicorp and Travelers, Inc. to create the world's largest financial conglomerate, Citigroup, a transaction that was announced on April 6, 1998). 2) There was a large turnover in our sample between 1997 and 1998 and the percentage of diversified firms was substantially larger among the entering than the exiting firms (a possible indication of this might be the substantial decrease in sample size between 1997 and 1998). 3) The change in the level of diversification is not due to changes in a firm's product portfolio, but rather to reporting changes only (i.e., no real changes in fact occurred). 4) Our sample inclusion restrictions lead to a bias in the percentage of diversified firms covered by the sample either before or after 1997/1998.

We choose different approaches to investigate these explanations for the jump in the level of diversified firms in our sample. First, we investigate whether our sample inclusion restrictions lead to a bias in the percentage of diversified firms included in the sample either before or after 1997/1998. We do this by comparing the total number of sample firms and all financial firms recorded in the Compustat files in each sample year. Additionally, we compare the percentage of focused firms in the sample and in the Compustat data for each sample year. In unreported tests, we find the number of financial firms in our sample and in the Compustat files to exhibit similar patterns, whereas the number (and percentage) of total firms excluded from our analysis increases sharply in 1993 and then remains at a high level. To a large extent, this finding is due to substantial increases in the number of investment trusts in the Compustat files from 1992 to 1993 and from 1993 to 1994, which remain at a high level until 2004. The percentages of focused firms in our sample and in the Compustat files exhibit similar patterns over the 20- 
year sample period, while the percentage of focused firms in our sample remains permanently below the corresponding number in the full Compustat sample by $10 \%$ to $20 \%$. The reason is that we exclude investment trusts, which account for 2,135 firm-year observations (34.5\%) and are primarily classified as focused. Summarizing, our sample inclusion restrictions are unlikely to be responsible for the jump in the percentage of diversified firms between 1997 and 1998.

As a next step, we investigate whether the valuation effect associated with functional diversification changes over time. Table 3 reports the mean and median sales- and asset-based excess value measure for focused and diversified firms for each calendar year in the sample. ${ }^{12}$ The results provide strong evidence in favor of a diversification discount. With the exception of 1985 and 1997 the mean and median excess value is always lower for diversified firms as compared to focused firms. Moreover, in 18 out of 20 sample years, at least one of the differences in means and medians between focused and diversified firms' sales- or asset-based excess value is statistically significant. In 10 of 20 sample years, the difference in mean and median excess value between focused and diversified firms is statistically significant for the sales- and asset-based measures, with diversified firms having lower values than focused firms.

While the exceptional absence of a significant conglomerate discount in 1985 may be due to the very small and possibly unrepresentative sample size, the finding that there is no conglomerate discount for the year 1997, and a relatively small and insignificant discount in the surrounding years (1996, 1998, and 2000) is more interesting. To shed some further light on points 1) to 3) above, we sought evidence regarding whether in fact the valuation (and degree of diversification) of the identical companies changes over time or whether low (high) valued diversified firms leave (enter) the sample and/or high (low) valued focused firms leave (enter) the sample. In a first step, we analyze the excess values and number of segments for the years 1995-2001 for only those firms which already were present in the sample in 1995. The results (not reported in a table) reveal patterns in excess values very similar to those reported in Table 3, indicating that the lower mean and median excess values in 1996-1998 are not due to firms entering and exiting the

\footnotetext{
${ }^{12}$ To save space, we do not report the results on the hybrid excess value measure as they are very similar to those on the sales- and asset-based excess value measures.
} 
sample, but to changes in the valuation of those firms that were already in the sample in 1995 and showed a high diversification discount at the time.

The number of 1995-firms drops by 57 from 1997 to 1998, while the total number of firms drops by 44 from 307 to 263 (see Table 2). With respect to firms entering and exiting the sample, we find that only 31.6\% (6) of the 19 newly-entering firms are classified as diversified, and on average these same firms have a negative excess value of 0.107 . That is, newly entering firms do not seem to be responsible for either the substantial decrease in excess value of diversified firms or the increase in the percentage of diversified firms in the sample from 1997 to 1998. The same is true for firms leaving the sample: 31.7\% (20) of the 63 firms leaving the sample between 1997 and 1998 are classified as diversified and show a negative excess value (-0.147) on average. We conclude that firms leaving the sample have more of a mitigating effect than an enhancing effect on our findings.

We investigate whether the change in the percentage of diversified sample firms and excess value is due to a change of in-sample firms or to firms exiting or entering the sample. Results (unreported) show that the 244 firms that are in our sample in both 1997 and 1998 experience a substantial decline in excess value between the two years - from 0.041 to -0.085 . Over this period 56 firms increase their degree of diversification (42 previously focused firms diversify and 14 diversified firms increase the number of product segments). In contrast, only 19 firms (three of which become focused) decrease the level of diversification. Hence, the jump in the percentage of diversified firms seems to be caused by in-sample firms increasing their level of diversification in 1998. Segment reporting changes from SIC to NAICS in 1997, so that the change in reporting practices might be (partly) responsible for the increase in diversification between 1997 and 1998. However, if this change in the percentage of diversified sample-firms is in fact caused by a change in reporting, the question arises why these changes are associated with substantial changes in excess value. The more plausible explanation is that the jump in diversification was associated with the aforementioned expected US regulatory changes and/or the Citigroup merger - the two events are clearly related, since the Citigroup merger was 
clearly in violation of regulatory limits on functional diversification at the time it was announced. ${ }^{13}$

It is also interesting to investigate whether firms entering or exiting the sample differ systematically from in-sample firms. We begin this analysis by testing for differences between all financial firms in the sample and firms that entered or left the sample during the period covered by the data. In a first step, we compare all firms entering the sample between 1986 and 2004 (i.e., firm-year observations it for which there are no data for year $t-1$ for firm $i$ ) with in-sample firms (i.e., firm-year observations it for which there are data at least for years $t-1$ to $t+1$ for firm $i$ ) and firms leaving the sample between 1986 and 2003 (i.e., firm-year observations it for which there are no data for year $t+1$ for firm i) and in sample-firms. The results (not reported in a table) indicate that firms entering and firms leaving the sample differ from in-sample firms with respect to basically every variable. For example, firms entering the sample have significantly higher excess values, are smaller, and less likely to be diversified than in-sample firms. In contrast, firms leaving the sample have significantly lower excess values, are smaller, and are less likely to be diversified than in-sample firms. Since focused and diversified firms differ in many respects (see Table 1), we repeat the analysis for focused firms and for diversified firms separately. Specifically, we compare focused firms entering/exiting the sample with other focused firms in the sample and diversified firms entering/exiting the sample with other diversified firms in the sample. The results (not reported in a table) indicate that focused and diversified firms exhibit significantly higher (lower) excess values when they enter (exit) the sample than do in-sample firms. Firms leaving the sample are less profitable and smaller (especially for diversified firms) than in-sample firms.

Finally, before switching to a multivariate setting, we investigate whether the conglomerate discount depends on the level of diversification (e.g., Lang and Stulz, 1994). The results are shown in Table 4 and report means and medians for all three excess value measures for different numbers of segments and for various values of the two HHIs. The results are consistent with those of Lang and Stulz (1994): There is a substan-

\footnotetext{
${ }^{13}$ The Citigroup merger announcement was subject to a two-year grace period, with three possible one-year extensions, during which time Congress had to change the functional barriers contained in the GlassSteagall legislation and the Bank Holding Company Act. Failing that, the merger would have had to be unwound. It therefore represented a high-stakes bet on pending US deregulation, and no doubt stimulated strategic rethinking among many other financial firms.
} 
tial drop in excess value between focused and diversified firms but once a firm is diversified, there is no additional discount associated with increasing the number of segments from two to three or more. Similarly, there is a substantial difference in excess value between firms with HHI values (sales- and asset-based) equal to one and firms with HHI values smaller than one, but only minor differences in excess value between firms with different HHI values less than one. The results for the sales-based HHI are shown in Panel B and for the asset-based HHI in Panel C of Table 4. For the sales-based HHI, there is a substantial drop in the sales-based, asset-based, and hybrid excess value (results for the latter two not reported) when a firm moves from one to two segments but no further discount beyond that. For the asset-based HHI, all three excess value measures (results for the latter two not reported) decrease nearly monotonically as the HHI decreases. However, there is still a large jump when firms move from one to a value below one, and smaller changes thereafter.

\section{Multivariate Regression Analysis}

In this section, we investigate the existence of a diversification discount for financial firms in a multivariate framework. First, we estimate multivariate pooled time-series cross-sectional regressions of excess value on our measures of diversification and a number of control variables. This estimation procedure has appeared in the literature for similar panel datasets (e.g., Denis, Denis and Yost, 2002; Fauver, Houston and Naranjo, 2004). However, the pooling of cross-sectional and time-series data neglects that observations of one specific firm for different years are not independent (clustering). The result is a biased and inconsistent estimator, i.e., the standard errors are deflated and therefore the $t$-statistics are inflated. To account for the dependence of observations within one specific firm (for different years), we use a cluster-robust regression specification, which treats each firm as a cluster (e.g., see Maury and Pajuste, 2005).

We include two control variables in our standard regression specification. The natural logarithm of total assets, $\ln$ (Assets), is included to cover the possibility that the observed differences in firm value are due to differences in efficiency between small and large firms rather than to the degree of diversification. The second control variable, Lev- 
erage, might affect firm value based on the role of debt in helping to discourage the overinvestment of free cash flow by self-serving managers (e.g., Jensen, 1986; Stulz, 1990; Hart and Moore, 1995). Debt can also create value by giving the management an opportunity to signal its willingness to distribute cash flows and to be monitored by lenders. Empirically, McConnell and Servaes (1995) find that book leverage is positively correlated with firm value when investment opportunities are scarce, which is consistent with the hypothesis that debt alleviates the overinvestment problem. Besides this agency- related motivation for the inclusion of leverage as a control variable, leverage might be of a special importance to financial firms. For example, a well-capitalized firm might have fewer incentives to engage in excessive risk-taking.

The results from estimating pooled cross-sectional time series regressions of the excess value measure based on sales (Panel A) and assets (Panel B), and the hybrid excess value measure based on sales and assets (Panel C) on measures of diversification and the two control variables are reported in Table 5. The results show that when we control for firm size and leverage, diversified firms still trade at a discount of between approximately 16\% (asset-based excess value measure) and 24\% (sales-based excess value measure). Excess value is also related negatively to the number of segments and related positively to the Herfindahl-Hirshman indices, confirming a diversification discount. With respect to the control variables, firm size is estimated to have a significantly positive effect on firm valuation and leverage to have a negative effect. ${ }^{14}$

We perform a battery of robustness tests for these results. First, we include a series of additional control variables: Lang and Stulz (1994) and Servaes (1996), for example, argue that it is possible that specialized firms have more trouble raising funds, and therefore exhibit a higher firm value than diversified firms because they are unable to exhaust available positive net present value projects. ${ }^{15}$ To control for this, we include a dummy variable that is equal to one if the firm paid a dividend in the respective year and

\footnotetext{
${ }^{14}$ Given that the US Gramm-Leach-Bliley Act of 1999 (GLB) eliminated functional barriers between commercial banking and insurance, and between commercial banking and investment banking, we divided the data into two sub-periods, before and after GLB. The coefficients in our standard regression equation (Table 5, Column 1) are basically identical and the differences are insignificant (results not reported), suggesting that the "level playing field" objective of GLB had little effect.

${ }^{15}$ In a neoclassical model in which firms have a stock of capital that they put to use with decreasing returns to scale, marginal excess firm value differs from one only if the firms cannot raise enough capital because of capital market imperfections (e.g., Lang and Stulz, 1994).
} 
zero otherwise. The reasoning is that dividend-paying firms could invest more by cutting dividends and thus are unlikely to be capital-constrained. Based on simple valuation models, we additionally include the return on assets as a measure of firm profitability. To control for growth opportunities, we include the past growth in sales (assets) which is calculated as the average annual growth of sales (assets) over the past three years (e.g., Yermack, 1996). ${ }^{16}$ Finally, as an alternative measure of a firm's growth prospects, we include the commonly used proxy of Tobin's q computed as the ratio of the market value of equity plus the book value of debt to the book value of total assets (e.g., Agrawal and Knoeber, 1996). While some of these control variables are estimated significant (q, past growth in sales and past growth in assets are in general estimated positive and significant while the dummy variable whether a firm pays a dividend and return on assets are never estimated significant), the negative valuation effect of diversification remains qualitatively similar and significant at the $1 \%$ level in all specifications. To save space, we do not report these results in a table.

To eliminate a potential omitted-variables bias and control for the effect of unobserved variables that are constant over time as well as unobserved variables that are constant over firms, we include calendar-year dummies and firm fixed-effects (not reported in the tables). The results from fixed effects regressions of the excess value measure based on sales are reported in Panel A of Table 6. Most important, the main results remain similar to those in Table 5. All measures of diversification exhibit the expected sign and are significant at the $1 \%$ level, whereas the size of the coefficients is somewhat reduced. For example, the coefficient on the diversification dummy variable in Column 1 indicates that diversified firms trade at a discount of roughly $16 \%$. In contrast to Table 5 , the coefficients related to the log of total assets are statistically insignificant. The results for the asset-based and the hybrid excess value measure are qualitatively similar. Therefore, we do not report them in a table.

We use Heckman's (1979) two-step procedure to control for the endogeneity of the diversification decision (e.g., see Campa and Kedia, 2002; Villalonga, 2004). In the first-step, we estimate a probit regression with a dummy variable whether the firm is di-

\footnotetext{
${ }^{16}$ Due to data availability sample size substantially decreases when we include these two variables resulting in 2880 firm-year observation on 488 firms.
} 
versified as the dependent variable. The choice of explanatory variables is based on Campa and Kedia (2002): the log of total assets, leverage, a dummy variable whether the firm pays a dividend, return on assets, a dummy variable whether the firm belongs to the S\&P500 index, a dummy variable whether the firm is listed at NYSE, the fraction of diversified firms and the fraction of sales accounted for by diversified firms in the industry, median industry q and its lagged value, the number of M\&A transactions in a given year (financial sector only), the annual value of completed M\&A deals in the financial sector in a given year, and GDP growth and its lagged value. ${ }^{17}$ We use the 4-digit NAICS (3digit SIC) codes to identify industries. In the second stage, we regress the sales-based excess value measure on the dummy variable whether the firm is diversified, the log of total assets, leverage, and the self-selection parameter (lambda). The results in Panel B of Table 6 (Column 4) reveal that the coefficient on the diversification dummy variable remains negative and significant while the self-selection parameter is positive and insignificant. Alternatively, we repeat the analysis by modelling the decision to diversify rather than being diversified as the firms' endogenous choice (e.g., see Villalonga, 2004). Specifically, in the first stage we estimate a probit regression with a dummy variable whether the firm diversified (i.e., increases the number of segments) as the dependent variable. The results in Column 5 reveal that the selection parameter (lambda) turns negative but remains insignificant while the coefficient on the diversification dummy variable remains basically unchanged. Finally, we check the robustness of these results by using alternative explanatory variables in the first stage probit regression (e.g., a dummy variable whether the firm is included in the S\&P financial instead of S\&P500 index, lagged values of the log of total assets and return on assets) and using the 3-digit NAICS (2-digit SIC) codes to identify industries, repeat the analysis for the asset-based excess value measure and the hybrid excess value measure, and omit the year dummy variables in the secondstage regression. However, the results change only immaterially. For brevity we do not report them in a table. Summarizing, the results of the endogenous self-selection model confirm the existence of a diversification discount in financial conglomerates and reveal that in contrast to non-financial firms self-selection does not seem to drive the results.

\footnotetext{
${ }^{17}$ Data on the number and value of M\&A transactions are from Thomson Financial's SDC (Securities Data Corporation) database, and data on GDP growth from NBER.
} 
We also investigate whether the conglomerate discount documented so far is related to firm size and leverage by including interaction terms between the diversification dummy variable and firm characteristics related to size and leverage in the standard regression specification as reported in Column 1 of Table 5. First we additionally include an interaction term between the diversification dummy variable and leverage. The results are reported in Column 1 of Table 7 and reveal that the diversification dummy variable becomes insignificant while the interaction term is negative and significant at the $1 \%$ level. Therefore, diversification seems to be value- decreasing only in firms with a high leverage ratio. ${ }^{18}$ This result is somewhat surprising, since corporate diversification is argued to increase a firm's debt capacity and therefore lead to higher interest tax shields (e.g., Lewellen, 1971). In addition, it contradicts Jensen's (1986) free cash flow hypothesis. However, as noted in the introduction, conflicts of interest among clients and activity areas of financial conglomerates can create incremental reputational risk (e.g., Walter, 2005) and therefore higher debt costs and a lower share price. Second, we include an interaction term between the diversification dummy variable and the log of total assets. The results in Column 2 indicate that the conglomerate discount increases with firm size. A possible reason for this finding might be that monitoring becomes more difficult in larger, more complex organizations leading to larger agency costs. Similarly, inefficient crosssubsidization among business lines might be fostered in such firms.

In Column 3, we additionally interact the diversification dummy variable with a dummy variable whether the firm has total assets above \$100bn. Based on this variable aiming at capturing the largest financial companies in our sample, we attempt to test whether our sample provides evidence on the existence of financial market perceptions of so-called "too big to fail” (TBTF) guarantees. ${ }^{19}$ Too big to fail guarantees, provided by the public at zero or below-market cost through the central bank or public guarantee agency, support the creditworthiness of the banking unit of a financial conglomerate and

\footnotetext{
${ }^{18}$ Here it is important to note that financial firms in general and banks in particular exhibit very high leverage ratios (see descriptive statistics in Table 1). Our results indicate that when a diversified firm increases leverage from $60 \%$ to $80 \%$, excess value decreases ceteris paribus by approximately $20 \%$.

${ }^{19}$ The Compustat database contains relatively few banks as compared to other types of financial firms, which could affect our excess value estimates in view of the absence of small-focused banks in the sample if banks in general carry higher valuations than other financial firms. Consequently, the "too-big-to-fail" results may be due to an overestimate of the excess value among the large banking firms contained in the sample.
} 
by extension the entire financial firm and therefore could lead to higher firm values. Interestingly, we find the interaction term between diversification and firm size to be negative and significant while the interaction term between diversification and the dummy variable whether or not the firm has assets above $\$ 100 \mathrm{bn}$ is positive and significant. This finding might indicate the existence of too big to fail guarantees in the largest financial conglomerates in our sample. In addition, we check the robustness of these results by estimating pooled OLS regressions and fixed-effects regressions including an interaction term between a dummy variable whether the firm has total assets above \$100bn and the diversification dummy variable. The coefficients (not reported in a table) are invariably positive and significant at least at the $5 \%$ level for the asset-based and $10 \%$ level for the sales-based excess value measure. The coefficients on all other variables remain qualitatively similar. This suggests that contractual guarantees such as deposit insurance and additional too big to fail support in crisis situations - both of which are nominally targeted solely on the commercial banking unit (whose failure could trigger systemic damage) of a multifunctional financial firm - are perceived by financial markets to extend to cover the entire firm in the perception of shareholders as reflected in equity market valuations.

One alternative explanation, which is also consistent with our results, is that the premium is attributable to investors anticipating greater growth in revenues and profits because of cross-selling (revenue economies of scope), as opposed to the effect of too big to fail provisions. A second alternative interpretation focuses on scale - if there are economies of scale in the financial services sector, each activity area in a small diversified firm is small, but if a very large firm is diversified over a number of scale-sensitive activities, each segment may well be large enough to harvest available scale economies. ${ }^{20}$ It is difficult to test this hypothesis directly. However, when we calculate excess values for various size-based sub-samples, we find a significantly positive excess value only for a small group of the largest (total assets exceeding $\$ 100$ bn) diversified firms, and a discount for all sub-samples consisting of diversified firms with total assets under \$100 bn. Importantly, the discount for diversified firms with total assets below $\$ 100$ bn shows no clear trend and does not increase monotonically as firm size decreases. Consequently, if economies of scale are in fact the primary reason for the premium associated with the

\footnotetext{
${ }^{20}$ For a review of the literature on economies of scale in financial services, see Walter (2004), Chapter 6.
} 
very largest diversified firms in our sample (as opposed to too big to fail effects), there would have to be a critical size at which economies of scale start to become important. We believe that our results are more consistent with too big to fail provisions being responsible for the premium associated with the largest among the diversified firms in our sample than with alternative explanations based on benefits from cross-selling and economies of scale. Still, the positive and significant coefficient on firm size in all regression equations suggest that there are in fact economies of scale in the financial sector.

We also investigate whether the premium changes after the US financial services M\&A volume peak in $2001 .^{21}$ Specifically, we investigate the mean and median excess values for two sub-samples, one from 1985 to 2000 and the other from 2002 to 2004. The results indicate that the premium of the largest sample firms substantially decreased after 2001 notably for firms with assets between $\$ 100$ and 200 billion (the mean and median are statistically insignificant in the 2002-2004 period). In contrast, for the largest firms with total assets equal to or exceeding $\$ 200$ billion the premium is quite high in the 20022004 period (although borderline significant due to the small sample size), but only roughly half the size of the premium in the 1985-2001 period. This suggests that investor expectations of diversification-driven synergies materially declined in the latter period. ${ }^{22}$

Prior research on non-financial firms (e.g., Berger and Ofek, 1995) showed that only unrelated diversification (i.e., diversification at the two-digit SIC level) is associated with a significant discount in firm value, while there are no penalties for related diversification (i.e., diversification at the four-digit SIC level). As noted in Section III, we construct the following variables to investigate this issue: 1) A dummy variable which is equal to one if a firm is diversified at the five- digit level for NAICS codes or the fourdigit-level for SIC codes, intended to measure related diversification; 2) A dummy variable which is equal to one if a firm is diversified at the three-digit level for NAICS codes or at the two-digit-level for SIC codes (i.e., reports segments which differ at the threedigit level NAICS or the two-digit-level SIC codes). This variable aims to measure unrelated diversification; 3) A dummy variable, which is equal to one if a firm has at least one

\footnotetext{
${ }^{21}$ For a review of financial services M\&A volumes, see Walter (2004), Chapter 2.

${ }^{22}$ As a further robustness test we estimate our regression equations based on weighted least squares where the weighting is based on total assets. The results remain basically unchanged. Therefore, we do not report them in a table.
} 
segment outside the financial services sector. As noted earlier, 162 firm-year observations (4.0\%) correspond to financial firms with at least one segment outside the financial services sector.

We find that of 1,643 diversified firm-year observations, 361 can be defined as related diversification (i.e., firms which are diversified at the five-digit level for NAICS codes or the four-digit-level for SIC codes) and 989 as unrelated diversification (i.e., firms which are diversified at the three-digit level for NAICS codes or the two-digit-level for SIC codes). 162 firm-year observations refer to firms which operate in at least one segment outside the financial sector. ${ }^{23}$

The results in Panel B of Table 7 show that, in contrast to non-financial firms, related and unrelated diversification seems to be associated with a similar discount for financial firms. Therefore we do not differentiate between related and unrelated diversification in the remainder of the paper. However, we do investigate whether the number of related and unrelated segments is significantly related to firm value: For all three "levels of relatedness,” the coefficient on the number of segments is negative and statistically significant at the $10 \%$ level or better (not reported in a table).

Finally, we investigate whether diversification outside the financial sector is associated with a higher discount than diversification within the financial sector. The results in Column 6 show that the 49 firms (162 firm-year observations) with operations outside the financial sector exhibit a similar discount as the other diversified firms in our sample. While the coefficient is somewhat higher, the statistical significance is lower as compared to the coefficients on related and unrelated diversification due a higher standard deviation. We repeated the analysis in Panel B for the excess value measure based on assets and the hybrid excess value measure. The results remain basically unchanged, and we do not report them in a table. ${ }^{24}$

\footnotetext{
${ }^{23}$ We also use an additional measure of diversification aiming to measure a level of diversification between the standard measures of related and unrelated diversification: A dummy variable, which is equal to one if a firm is diversified at the four-digit level for NAICS codes or the three-digit-level for SIC codes. 1239 firmyear observations can be classified as diversified at this "in-between" level. The regression coefficients (not reported in a table) are very close to those reported for related and unrelated diversification in Panel B of Table 7.

${ }^{24}$ Table 7 reports results for cluster-robust pooled cross-sectional time series regressions. The results for fixed-effects regressions are qualitatively similar - therefore, we do not report them in a table.
} 


\section{Changes in Diversification and Excess Value}

So far, our analysis shows that financial conglomerates trade at a discount as compared to focused firms in the financial sector. This raises the question of causality whether firms that diversify are already trading at a discount prior to the diversification, or whether their value decreases as a result of the diversification. One way to investigate this issue relies on Heckman's (1979) self-selection model (e.g., see Campa and Kedia, 2002; Villalonga, 2004; or our analysis in Section V). In this section we undertake an alternative analysis and test whether a change in the degree of diversification is associated with a change in excess value. If diversified firms already trade at a discount before they diversify, this indicates that it is not diversification that causes the discount but that diversification might be a firm's reaction to poor performance. With respect to non-financial firms, the results of Lang and Stulz (1994) indicate that firms in poorly-performing industries tend to diversify, but not that poorly-performing firms in a given industry diversify. More recently Campa and Kedia (2002) show, based on different econometric techniques including Heckman's self-selection model, that firms do indeed tend to diversify away from industries experiencing difficulties into more promising industries. However, Comment and Jarrell (1995) find that an increase in the degree of diversification is associated with a significant drop in stock returns while an increase in focus is associated with a substantial increase in stock returns - their results show that a change of 0.1 in the absolute value of a sales-based HHI is associated with a stock return of about $4 \%$, and that adding or subtracting one business segment is associated with a difference in returns of about $5 \%$.

The descriptive results in Table 8 show that changes in diversification and focus are rather equally distributed in the financial services industry over the full sample period, although (as already shown in Table 2), an unusually large number of changes occurred in 1998. Overall, 56 firms increased the degree of diversification and 19 increased focus, while the averages over the 19 years from 1986 to 2004 are 10.47 and 8.21, respectively. $^{25}$

\footnotetext{
${ }^{25}$ In percentage terms, $21.29 \%$ of all sample firms experience an increase in the degree of diversification in 1998 and $7.22 \%$ an increase in focus. The sample averages from 1986 to 2004 are $4.90 \%$ and 3.84\%, respectively.
} 
In Table 9 we investigate whether diversified firms already trade at a discount before they diversify or whether a discount appears only after the diversification. Panel A reports means and medians for the sales-based excess value measure for up to three years before a change in diversification or focus. The results show that previously focused firms that diversify at some point during our sample period do not trade at a discount before diversification. Panel B reports the results of univariate OLS regressions of the change in excess value between years $t$ and $t-1$ on a dummy variable, which is set equal to one if a previously focused firm diversifies (Column 1), a diversified firm increases the number of segments (Column 2), a diversified firm decreases the number of segments (Column 3), and a previously diversified firm refocuses (Column 4), respectively. Consistent with the findings of Comment and Jarrell (1995), we find that an increase in focus is positively related to firm value and a decrease in focus (or increase in diversification) is negatively related to firm value. The effect is stronger: (1) For previously diversified firms that become focused than for diversified firms that decrease the number of segments; and (2) for previously focused firms that become diversified than for diversified firms that increase the number of segments. ${ }^{26}$

In combination, the results in Panels A and B suggest that it is diversification that causes the discount, and not troubled firms diversifying into other, more promising areas. In contrast, focusing firms trade at a very large discount before they decrease the number of segments in which they were active, or become completely focused. This finding suggests that the increase in focus may be due to external pressure (e.g., by active shareholders). ${ }^{27}$

\footnotetext{
${ }^{26}$ In unreported tests we also find that firms that increase focus experience a further significant increase in firm value over the subsequent year. In contrast, the change in excess value for focused firms that diversify remains negative for the following year but not statistically significant. Somewhat surprisingly, diversified firms increasing the number of segments experience a significant increase in excess value in the subsequent year, which exceeds the decrease in the previous year in economic as well as statistical terms. Hence, given that a firm is already diversified a further diversification may be value increasing on average.

${ }^{27}$ Beiner and Schmid (2005), for example, show that in their Swiss sample the probability that a firm is diversified is negatively related to the prevalence of large outside blockholders.
} 


\section{Geographic diversification}

Recent research shows that not only functional diversification but also geographic diversification is associated with a lower market value (e.g., see Denis, Denis and Yost; 2002, Fauver, Houston and Naranjo, 2004). However, the empirical evidence is not conclusive. Bodnar, Tang, and Weintrop (1999), for example, find a slight premium associated with geographical diversification in the sample of U.S. non-financial firms covering the period 1984 to 1997. To our knowledge, there is no evidence so far on the relation between geographical diversification and firm value for financial intermediaries, ${ }^{28}$ although DeLong (2001b) argues that an analysis of the geographic dimension of diversification is more interesting for financial than non-financial firms since - in contrast to most manufacturing firms - financial services firms demand proximity to the client. Schoenmaker and van Laake (2006) show that geographic diversification among European banks exceeds that among US and Asian banks, but do not link this to an excess value measure. The empirical analysis in this section aims to fill this gap by including the geographic dimension of diversification into our analysis.

One problem with the geographic segment data compiled by Compustat is that there is no requirement by either the Financial Accounting Standards Board or the Securities and Exchange Commission regarding the grouping for geographic areas (e.g., see Denis, Denis, and Yost, 2002). Therefore, some firms report segment data for different countries, others for different continents or geographic areas (e.g., Southeast Asia), while some firms report segment data for countries and continents. As a result, two firms with identical operations in the same countries might report them very differently, and the number of geographic segments reported therefore becomes a problematic measure of the degree of geographic diversification. As a proxy, Denis, Denis, and Yost (2002) instead use the percentage of sales (assets) from non-domestic operations. In our database, for 3,153 (out of 4,703) foreign segments the reported sales are zero. Since this number is only 13 (out of 6,320) for domestic segments, it suggests that financial firms regularly book sales from foreign operations as sales from domestic segments, and that this meas-

\footnotetext{
${ }^{28}$ However, there is some evidence on the announcement effect associated with focusing and diversifying bank mergers. DeLong (2001a), for example, shows for a sample of domestic U.S. mergers (where at least one firm is a bank) that bank mergers that focus both functional and geographic activities enhance firm value by roughly $3 \%$ while other mergers do not create value.
} 
ure of geographic diversification has limited meaning. Hence, we concentrate on a dummy variable - i.e., whether a firm reports more than one geographic segment in the Compustat Segment files. $^{29}$

Table 10 gives an overview of the number of sample firms for each calendar year along with the number (and percentage) of geographically focused and diversified firms. The data show that the percentage of diversified and focused firms remains on a relatively constant level between 1985 and 1997, following which there is a substantial increase (decrease) in the percentage of geographically focused (diversified) firms between the years 1997 and 1998 as well as between 1998 and 1999. This was a likely consequence of repeal of the McFadden Act and the Riegle-Neal Interstate Banking and Branching Efficiency Act, both passed in 1994, which transformed the American banking system by eliminating geographic barriers and driving consolidation though M\&A activity that roughly halved the number of US banks over a decade.

To investigate whether the benefits of geographic diversification outweigh its costs, we employ the same multivariate framework we used in the analysis of functional diversification. Specifically, we add a dummy variable whether or not a firm is geographically diversified into the regression equation reported in Column 1 of Table 5. The results in Table 11 (Column 1) reveal that geographic diversification is not associated with a discount, but rather a small (statistically insignificant) premium, on average, while the coefficient on functional diversification remains negative and significant at the $1 \%$ level.

We also investigate whether the valuation effect of geographic diversification is related to firm size and leverage by estimating similar regression as reported in Panel A of Table 7, whereas we now interact geographic instead of functional diversification with the leverage and size variables. The results in Columns 2 to 4 of Table 11 reveal that, in contrast to functional diversification, the valuation effect of geographic diversification does not seem to be related to leverage or firm size. However, the interaction term between geographic diversification and the dummy variable whether the firm has total as-

\footnotetext{
${ }^{29}$ Another particularity in the data on geographic segments is that numerous firms report sales and/or assets figures of -0.01 for one segment. If the segment name applies to countries rather than continents or geographic areas, these segments often refer to Bermuda or a similar location - suggesting a letterbox company operated for tax reasons. Consequently, we do not treat these segments separately.
} 
sets above $\$ 100 \mathrm{bn}$ is positive and significant at the $10 \%$ level, again indicating the existence of too-big-to-fail guarantees in the largest financial conglomerates (Column 4).

We then investigate whether the valuation effect of geographic diversification depends on whether a firm is functionally diversified or focused by additionally including an interaction term between functional and geographic diversification in the regression equation reported in Column 1 of Table 11. The results in Column 5 reveal that the coefficient on functional diversification remains negative and significant at the $1 \%$ level while the coefficients on geographic diversification and on the interaction term are both positive but insignificant. Alternatively, we run the regression reported in Column 1 for the two sub-samples of diversified firm-year observations and focused firm-year observations separately. The results in Columns 6 and 7 of Table 11 show that geographic diversification is significantly positively related to firm value for functionally diversified firms only (Column 7) but not for functionally focused firms (Column 6). This result suggests that, conditional on being diversified functionally, geographic diversification is valueenhancing. We also investigate whether the valuation effect of functional diversification depends on whether a firm is geographically diversified. The results (not reported in a table) show that functional diversification is significantly negatively related to excess value irrespective of whether or not a firm is geographically diversified.

Summarizing, our results do not confirm those of Denis, Denis and Yost (2002) and Fauver, Houston and Naranjo (2004) for non-financial firms. On average, geographic diversification is not value destroying in financial firms but rather related to a small premium.

Finally, we investigate whether changes in the degree of geographic diversification are related to significant changes in firm value. We reproduce the analysis of Table 9 for changes in geographic diversification. For the sake of brevity we do not report the results in a separate table. They show that there were less frequent changes in geographic than in functional diversification, with the change from geographic diversification (more than one segment) to focus (only one segment) being by far the most frequent. This is not surprising given the evidence in Table 10. As in the case of functional diversification, there is a noticeable accumulation of changes in the level of geographic diversification in the five years centered on 1998, as discussed earlier. 
In general, there seems to be no clear pattern in excess value changes before firms change their degree of geographic diversification, with one exception - previouslyfocused firms which diversify geographically experience a steady and significant increase in excess value over the three-year period before geographic diversification, from an average excess value of -0.23 in year $t-3$ to -0.08 in year $t-1$ and -0.03 in year $t$ ). This suggests that well-performing firms seek to export their success to other markets. On the other hand, we do not find any of the changes in the degree of geographic diversification to be significantly related to a change in excess value, which contrasts with our findings on functional diversification.

\section{Conclusions}

Two of the enduring issues related to the industrial organization of financial intermediation relate to scale and scope. Is bigger better? Is broader better? The latter, in turn, can have either functional or geographic dimensions, or both. A great deal of research has focused on scale, both in terms of firm-wide cost functions and at the level of individual financial intermediation activities. Much less research has focused on scope, both with respect to costs and revenues, despite the myriad conceptual arguments for and against, in part because the difficult empirical issues involved. This paper addresses one of the key aspects of the debate on scope in financial intermediation - whether or not broader functional and geographic scope is value-enhancing or value-destroying.

We show that the impact of functional scope among financial intermediaries is predominantly value-destroying. Financial services conglomerates appear to trade at a discount from specialized financial firms for the same reasons that non-financial firms have been found to trade at a discount, and therefore impair both competitive performance and shareholder value. On balance, the negative elements present in financial conglomerates outweigh the positive elements. We also show that, in contrast, the benefits of geographic diversification seem to outweigh its costs, leading to value enhancement. The results on both dimensions are both statistically significant and robust. Finally, we show that perceived too-big-to-fail support to prevent systemic effects in crisis situations appears to extend beyond the banking units of multifunctional financial firms to the entire 
firms themselves, and is sufficient to overcome the conglomerate discount in market valuations.

Our findings are of interest for charting the strategic configuration of financial intermediaries, as well as for public policy. Scope-related and geographic economies and diseconomies have a key bearing on the structure and performance of national and global financial systems. 


\section{References}

Agrawal, A., and C.R. Knoeber. "Firm performance and mechanisms to control agency problems between managers and shareholders.” Journal of Financial and Quantitative Analysis, 31 (1996), 377-397.

Ahn, S., Denis, D.J., and D.K. Denis. "Leverage and investment in diversified firms.” Journal of Financial Economics, 79 (2006), 317-337.

Beiner, S., and M.M. Schmid. "Agency conflicts, corporate governance, and corporate diversification - Evidence from Switzerland.” Working Paper, University of Basel, Switzerland (2005).

Berger, A.N., and D.B. Humphrey. "Measurement and efficiency issues in commercial banking.” In Output measurement in the service sector, Z. Griliches, ed., Chicago, IL: University of Chicago Press (1992).

Berger, P.G., and E. Ofek. “Diversification’s effect on firm value.” Journal of Financial Economics, 37 (1995), 39-65.

Bodnar, G.M., Tang, C., and J. Weintrop. "Both sides of corporate diversification: The value impacts of geographic and industrial diversification.” Working Paper, Johns Hopkins University (1999).

Boyd, J., Graham, S., and R.S. Hewitt. "Bank holding company mergers with non-bank financial firms: Effects on the risk of failure.” Journal of Financial Economics, 17 (1993), 43-63.

Brewer, E., Jackson, W., Jagtiani, J., and T. Nguyen. “The price of bank mergers in the 1990s.” Federal Reserve Bank of Chicago Economic Perspectives, March (2000).

Campa, J.M., and S. Kedia. “Explaining the diversification discount.” Journal of Finance, 57 (2002), 1731-1762. 
Chen, S.-S., and K.W. Ho. "Corporate diversification, ownership structure, and firm value - The Singapore evidence.” International Review of Financial Analysis, 9 (2000), 315-326.

Clark, J.A.. "Economies of scale and scope at depository financial institutions: A review of the literature.” Federal Reserve Bank of Kansas City Economic Review, 73 (1988), September-October, 16-33.

Comment, R., and G.A. Jarrell. “Corporate focus and stock returns.” Journal of Financial Economics, 37 (1995), 67-87.

Cornett, M.M., and H. Tehranian. "Changes in corporate performance associated with bank acquisitions.” Journal of Financial Economics, 31 (1992), 211-234.

Cornett, M.M., Hovakimian, G., Palia, D., and H. Tehranian. "The impact of the manager-shareholder conflict on acquiring bank returns.” Journal of Banking and Finance, 27 (2003), 103-131.

DeLong, G. "Stockholder gains from focusing versus diversifying bank mergers." Journal of Financial Economics, 59 (2001a), 221-252.

DeLong, G. "Focusing versus diversifying bank mergers: Analysis of market reaction and long-term performance.” Working Paper, CUNY (2001b).

Denis, D.J., Denis, D.K., and A. Sarin. “Agency problems, equity ownership, and corporate diversification.” Journal of Finance, 52 (1997), 135-160.

Denis, D.J., Denis, D.K., and K. Yost. "Global diversification, industrial diversification, and firm value.” Journal of Finance, 57 (2002), 1951-1979.

Fauver, L., Houston. J.F., and A. Naranjo. "Cross-country evidence on the value of corporate industrial and international diversification.” Journal of Corporate Finance, 10 (2004), 729-752. 
Hart, O., and J. Moore. "Debt and seniority - An analysis of the role of hard claims in constraining management.” American Economic Review, 85 (1995), 567-585.

Heckman, J. "Sample selection bias as specification error.” Econometrica, 47 (1979), 153-161.

Houston, J., James, C., and M. Ryngaert. "Where do merger gains come from? Bank mergers from the perspective of insiders and outsiders.” Journal of Financial Economics, 60 (2001), 285-331.

Houston, J., and M. Ryngaert. “The overall gains from large bank mergers.” Journal of Banking and Finance, 18 (1994), 1155-1176.

Jensen, M., “Agency costs of free cash flow, corporate finance, and takeovers.” American Economic Review, 76 (1986), 323-329.

Laeven, L., and R. Levine. "Is there a diversification discount in financial conglomerates?” Journal of Financial Economics, forthcoming (2005).

Lang, L.H.P., and R.M. Stulz. “Tobin’s q, corporate diversification, and firm performance.” Journal of Political Economy, 102 (1994), 1248-1280.

Lewellen, W. “A pure financial rationale for the conglomerate merger.” Journal of Finance, 26 (1971), 521-537.

Lins, K., and H. Servaes. "International evidence on the value of corporate diversification.” Journal of Finance, 54 (1999), 2215-2239.

Lown, C.S., Osler, C.L., Strahan, P.E., and A. Sufi. “The changing landscape of the financial services industry: What lies ahead?” Federal Reserve Bank of New York Economic Policy Review, October (2000), 39-55.

Maury, B., and A. Pajuste. "Multiple large shareholders and firm value.” Journal of Banking and Finance, 29 (2005), 1813-1834. 
McConnell, J., and H. Servaes. “Equity ownership and the two faces of debt.” Journal of Financial Economics, 39 (1995), 131-157.

Mitchell, K., and N. Onvural. "Economies of scale and scope at large commercial banks: Evidence from the Fourier Flexible Functional Form.” Journal of Money, Credit and Banking, 28 (1996), 178-199.

Santomero, A. "Financial risk management: The whys and hows.” Financial Markets, Institutions and Instruments, 4 (1995), 1-14.

Santomero, A., and E. J. Chung. “Evidence in support of broader bank powers.” Financial Markets, Institutions, and Instruments, 1 (1992), 1-69.

Saunders, A., and I. Walter. "Universal banking in the United States.” New York: Oxford University Press (1994).

Schoenmaker, D., and C. van Laake. “Current state of cross-border banking.” Federal Reserve Bank of Chicago, Conference on financial instability: Cross-border banking and financial regulation, September (2006).

Servaes, H. “The value of diversification during the conglomerate merger wave.” Journal of Finance, 51 (1996), 1201-1225.

Stiroh, K.J., and A. Rumble. "The dark side of diversification: The case of US financial holding companies.” Journal of Banking and Finance, 30 (2006), 2131-2161.

Stulz, R. "Managerial discretion and optimal financing policies.” Journal of Financial Economics, 26 (1990), 3-27.

Villalonga, B. “Does diversification cause the diversification discount?” Financial Management, 33 (2004), 5-27.

Walter, I. "Mergers and acquisitions in banking and finance.” New York: Oxford University Press (2004). 
Walter, I. "Conflicts of interest and market discipline in financial services firms." In Market discipline across countries and industries, C. Borio, W.C. Hunter, G.G. Kaufman, K. Tsatsaronis, eds., Cambridge, MA: MIT Press (2005).

Yermack, D. "Higher market valuation of companies with a small board of directors." Journal of Financial Economics, 40 (1996), 185-211.

Yu, L. "On the wealth and risk effects of the Glass-Steagall overhaul: Evidence from the stock market.” Working Paper, New York University (2002). 
Table 1: Comparison of focused and diversified firms

\begin{tabular}{|c|c|c|c|c|c|c|c|c|}
\hline & \multicolumn{3}{|c|}{ Focused } & \multicolumn{3}{|c|}{ Diversified } & \multicolumn{2}{|c|}{ Difference } \\
\hline & Mean & Median & $\mathrm{N}$ & Mean & Median & $\mathrm{N}$ & Mean & Median \\
\hline Excess value (sales) & -0.030 & 0.000 & 2417 & -0.188 & -0.209 & 1643 & $0.158 * \star \star$ & $0.209 * * *$ \\
\hline Excess value (assets) & 0.004 & 0.000 & 2478 & -0.194 & -0.170 & 1436 & $0.198 * \star *$ & $0.170 * * *$ \\
\hline Excess value (hybrid) & -0.017 & 0.000 & 2439 & -0.173 & -0.190 & 1643 & $0.157 * * *$ & $0.190 * \star *$ \\
\hline Number of segments & 1.000 & 1.000 & 2417 & 2.884 & 3.000 & 1643 & $-1.884 * * *$ & $-2.000 * * *$ \\
\hline Herfindahl (sales) & 1.000 & 1.000 & 2417 & 0.664 & 0.645 & 1601 & $0.337^{\star \star *}$ & 0.356 *** \\
\hline Herfindahl (assets) & 1.000 & 1.000 & 2339 & 0.658 & 0.639 & 1454 & $0.342^{\star \star *}$ & $0.361^{\star \star *}$ \\
\hline Total assets & 4469.657 & 580.340 & 2417 & 17743.180 & 3227.630 & 1643 & $-13273.523^{\star \star *}$ & $-2647.290 * \star \star$ \\
\hline Sales & 734.302 & 203.360 & 2417 & 3565.509 & 943.900 & 1643 & $-2831.207^{\star \star \star}$ & $-740.540 * \star \star$ \\
\hline Leverage & 0.683 & 0.743 & 2411 & 0.774 & 0.813 & 1643 & $-0.091 * * \star$ & $-0.070 * * *$ \\
\hline Market value of company & 3816.569 & 419.924 & 2417 & 7349.805 & 1342.898 & 1643 & -3533.236 *** & -922.974 *** \\
\hline Market-to-book value & 1.845 & 1.263 & 2411 & 1.502 & 1.193 & 1643 & $0.342^{* * *}$ & $0.070 * * *$ \\
\hline $\mathrm{Q}$ & 1.484 & 1.117 & 2411 & 1.237 & 1.048 & 1643 & $0.247^{\star \star \star}$ & $0.069 * * *$ \\
\hline Return on assets & 0.041 & 0.030 & 2417 & 0.025 & 0.019 & 1643 & $0.016 * * *$ & $0.012^{* * *}$ \\
\hline Dividend dummy variable & 0.658 & 1.000 & 2417 & 0.825 & 1.000 & 1643 & $-0.167^{\star \star \star}$ & $0.000 * * *$ \\
\hline Intangible to total assets & 0.065 & 0.001 & 2020 & 0.059 & 0.012 & 1196 & 0.006 & $-0.011^{* * *}$ \\
\hline
\end{tabular}

This table presents mean and median values and the number of observations $(N)$ for all variables used in the study for single- (focused) and multi-segment (diversified) firms separately. All firms reporting more than one segment (with differing SIC or NAICS) codes are classified as diversified. The equality of means is tested using a standard $t$-test and the equality of medians using a non-parametric Mann-Whitney test. ***/**/* denotes statistical significance at the $1 \% / 5 \% / 10 \%$ level. 
Table 2: Sample overview by calendar year

\begin{tabular}{rrrrrr}
\hline Year & Focused & Focused (\%) & Diversified & Diversified (\%) & N \\
\hline 1985 & 22 & $46.81 \%$ & 25 & $53.19 \%$ & 47 \\
1986 & 76 & $53.90 \%$ & 65 & $46.10 \%$ & 141 \\
1987 & 80 & $52.63 \%$ & 72 & $47.37 \%$ & 152 \\
1988 & 77 & $51.33 \%$ & 73 & $48.67 \%$ & 150 \\
1989 & 75 & $52.08 \%$ & 69 & $47.92 \%$ & 144 \\
1990 & 71 & $54.62 \%$ & 59 & $45.38 \%$ & 130 \\
1991 & 93 & $61.59 \%$ & 58 & $38.41 \%$ & 151 \\
1992 & 113 & $63.48 \%$ & 65 & $36.52 \%$ & 178 \\
1993 & 161 & $67.36 \%$ & 78 & $32.64 \%$ & 239 \\
1994 & 181 & $67.04 \%$ & 89 & $32.96 \%$ & 270 \\
1995 & 205 & $69.97 \%$ & 88 & $30.03 \%$ & 293 \\
1996 & 230 & $72.56 \%$ & 87 & $27.44 \%$ & 317 \\
1997 & 213 & $69.38 \%$ & 94 & $30.62 \%$ & 307 \\
1998 & 144 & $54.75 \%$ & 119 & $45.25 \%$ & 263 \\
1999 & 121 & $54.26 \%$ & 102 & $45.74 \%$ & 223 \\
2000 & 112 & $53.59 \%$ & 97 & $46.41 \%$ & 209 \\
2001 & 111 & $53.62 \%$ & 96 & $46.38 \%$ & 207 \\
2002 & 104 & $52.00 \%$ & 96 & $48.00 \%$ & 200 \\
2003 & 115 & $52.75 \%$ & 103 & $47.25 \%$ & 218 \\
2004 & 113 & $51.13 \%$ & 108 & $48.87 \%$ & 221 \\
Sum & & & & & 4060 \\
\hline & 2417 & & 1643 & & \\
\hline
\end{tabular}

This table reports the number and percentage of focused firms in the sample, the number and percentage of diversified firms in the sample, and the number of total observations $(N)$ for each sample calendar year. All firms reporting more than one segment (with differing SIC or NAICS) codes are classified as diversified. 
Table 3: Excess value for each calendar year (1985-2004)

\begin{tabular}{|c|c|c|c|c|c|c|}
\hline \multirow[b]{2}{*}{ Year } & \multicolumn{2}{|c|}{ Focused } & \multicolumn{2}{|c|}{ Diversified } & \multicolumn{2}{|c|}{ Difference } \\
\hline & $\begin{array}{l}\text { Excess Value } \\
\text { (Sales) }\end{array}$ & $\begin{array}{r}\text { Excess Value } \\
\text { (Assets) }\end{array}$ & $\begin{array}{r}\text { Excess Value } \\
\text { (Sales) }\end{array}$ & $\begin{array}{l}\text { Excess Value } \\
\text { (Assets) }\end{array}$ & $\begin{array}{l}\text { Excess Value } \\
\text { (Sales) }\end{array}$ & $\begin{array}{l}\text { Excess Value } \\
\text { (Assets) }\end{array}$ \\
\hline 1985 & $\begin{array}{r}0.0106 \\
(0.0000)\end{array}$ & $\begin{array}{r}0.0106 \\
(0.0000)\end{array}$ & $\begin{array}{r}0.1411 \\
(0.1100)\end{array}$ & $\begin{array}{r}0.1745 \\
(0.1711)\end{array}$ & $\begin{array}{r}-0.1305 \\
(-0.1100)\end{array}$ & $\begin{array}{r}-0.1639 \\
(-0.1711)\end{array}$ \\
\hline 1986 & $\begin{array}{r}-0.0272 \\
(-0.0031)\end{array}$ & $\begin{array}{r}-0.0272 \\
(-0.0031)\end{array}$ & $\begin{array}{r}-0.1578 \\
(-0.1888)\end{array}$ & $\begin{array}{r}-0.1581 \\
(-0.2424)\end{array}$ & $\begin{array}{c}0.1306 \\
(0.1857) *\end{array}$ & $\begin{array}{c}0.1309 \\
(0.2393)^{\star \star}\end{array}$ \\
\hline 1987 & $\begin{array}{l}-0.0353 \\
(0.0000)\end{array}$ & $\begin{array}{r}-0.0353 \\
(0.0000)\end{array}$ & $\begin{array}{r}-0.1536 \\
(-0.1530)\end{array}$ & $\begin{array}{r}-0.1690 \\
(-0.1560)\end{array}$ & $\begin{array}{c}0.1184 \\
(0.1530) *\end{array}$ & $\begin{array}{c}0.1338 \\
(0.1560) * *\end{array}$ \\
\hline 1988 & $\begin{array}{r}-0.0547 \\
(0.0000)\end{array}$ & $\begin{array}{r}-0.0567 \\
(0.0000)\end{array}$ & $\begin{array}{r}-0.2019 \\
(-0.2600)\end{array}$ & $\begin{array}{r}-0.2481 \\
(-0.2854)\end{array}$ & $\begin{array}{r}0.1471 \text { * } \\
(0.2600)^{*}\end{array}$ & $\begin{array}{c}0.1914 \text { ** } \\
(0.2854)^{*}\end{array}$ \\
\hline 1989 & $\begin{array}{r}-0.0452 \\
(0.0000)\end{array}$ & $\begin{array}{r}-0.0476 \\
(-0.0011)\end{array}$ & $\begin{array}{r}-0.2777 \\
(-0.3409)\end{array}$ & $\begin{array}{r}-0.3147 \\
(-0.3584)\end{array}$ & $\begin{array}{c}0.2325^{* *} \\
(0.3409)^{* * *}\end{array}$ & $\begin{array}{r}0.2671^{* * *} \\
(0.3573)^{* * *}\end{array}$ \\
\hline 1990 & $\begin{array}{r}-0.0473 \\
(-0.0021)\end{array}$ & $\begin{array}{r}-0.0473 \\
(-0.0021)\end{array}$ & $\begin{array}{r}-0.1797 \\
(-0.2307)\end{array}$ & $\begin{array}{r}-0.1912 \\
(-0.2409)\end{array}$ & $\begin{array}{c}0.1324 \\
(0.2286) *\end{array}$ & $\begin{array}{c}0.1439 \\
(0.2388) * \star\end{array}$ \\
\hline 1991 & $\begin{array}{r}-0.0136 \\
(-0.0092)\end{array}$ & $\begin{array}{r}-0.0136 \\
(-0.0092)\end{array}$ & $\begin{array}{r}-0.2003 \\
(-0.1344)\end{array}$ & $\begin{array}{r}-0.2028 \\
(-0.2065)\end{array}$ & $\begin{array}{c}0.1867 \text { * } \\
(0.1252)\end{array}$ & $\begin{array}{c}0.1892 \text { * } \\
(0.1973)\end{array}$ \\
\hline 1992 & $\begin{array}{r}-0.0381 \\
(-0.0628)\end{array}$ & $\begin{array}{r}-0.0381 \\
(-0.0628)\end{array}$ & $\begin{array}{r}-0.3402 \\
(-0.4438)\end{array}$ & $\begin{array}{r}-0.3688 \\
(-0.4748)\end{array}$ & $\begin{array}{r}0.3020 \text { *** } \\
(0.3810)^{\star * \star}\end{array}$ & $\begin{array}{r}0.3306^{* * *} \\
(0.4120)^{* * *}\end{array}$ \\
\hline 1993 & $\begin{array}{l}-0.0096 \\
(0.0000)\end{array}$ & $\begin{array}{r}-0.0099 \\
(0.0000)\end{array}$ & $\begin{array}{r}-0.2834 \\
(-0.2940)\end{array}$ & $\begin{array}{r}-0.2549 \\
(-0.2940)\end{array}$ & $\begin{array}{r}0.2738^{* \star *} \\
(0.2940) * * *\end{array}$ & $\begin{array}{r}0.2450 \text { *** } \\
(0.2940)^{* * *}\end{array}$ \\
\hline 1994 & $\begin{array}{r}0.0134 \\
(-0.0196)\end{array}$ & $\begin{array}{r}0.0128 \\
(-0.0196)\end{array}$ & $\begin{array}{r}-0.1539 \\
(-0.1884)\end{array}$ & $\begin{array}{r}-0.1509 \\
(-0.1781)\end{array}$ & $\begin{array}{r}0.1673^{* *} \\
(0.1688)^{* *}\end{array}$ & $\begin{array}{c}0.1637^{* \star} \\
(0.1585)^{\star \star \star}\end{array}$ \\
\hline 1995 & $\begin{array}{r}-0.0349 \\
(0.0000)\end{array}$ & $\begin{array}{r}-0.0348 \\
(0.0000)\end{array}$ & $\begin{array}{r}-0.2138 \\
(-0.2356)\end{array}$ & $\begin{array}{r}-0.2346 \\
(-0.2972)\end{array}$ & $\begin{array}{r}0.1789 \text { ***} \\
(0.2356) * \star\end{array}$ & $\begin{array}{r}0.1998^{* * *} \\
(0.2972)^{* * *}\end{array}$ \\
\hline 1996 & $\begin{array}{r}-0.0561 \\
(-0.0096)\end{array}$ & $\begin{array}{r}-0.0559 \\
(-0.0096)\end{array}$ & $\begin{array}{r}-0.1394 \\
(-0.1721)\end{array}$ & $\begin{array}{r}-0.1461 \\
(-0.2254)\end{array}$ & $\begin{array}{c}0.0833 \\
(0.1626) *\end{array}$ & $\begin{array}{c}0.0902 \\
(0.2158) *\end{array}$ \\
\hline 1997 & $\begin{array}{r}0.0091 \\
(0.0000)\end{array}$ & $\begin{array}{r}0.0048 \\
(0.0000)\end{array}$ & $\begin{array}{r}0.0250 \\
(-0.0408)\end{array}$ & $\begin{array}{r}0.0198 \\
(-0.0226)\end{array}$ & $\begin{array}{r}-0.0159 \\
(0.0408)\end{array}$ & $\begin{array}{r}-0.0151 \\
(0.0226)\end{array}$ \\
\hline 1998 & $\begin{array}{r}-0.0108 \\
(0.0000)\end{array}$ & $\begin{array}{r}0.0052 \\
(0.0000)\end{array}$ & $\begin{array}{r}-0.1053 \\
(-0.0981)\end{array}$ & $\begin{array}{r}-0.0816 \\
(-0.0988)\end{array}$ & $\begin{array}{c}0.0945 \\
(0.0981) *\end{array}$ & $\begin{array}{r}0.0868 \\
(0.0988)\end{array}$ \\
\hline 1999 & $\begin{array}{r}-0.0252 \\
(0.0000)\end{array}$ & $\begin{array}{r}-0.0076 \\
(0.0001)\end{array}$ & $\begin{array}{r}-0.1716 \\
(-0.1505)\end{array}$ & $\begin{array}{r}-0.0809 \\
(-0.0945)\end{array}$ & $\begin{array}{c}0.1463^{\star \star} \\
(0.1505)^{\star \star \star}\end{array}$ & $\begin{array}{c}0.0734 \\
(0.0946) * \star\end{array}$ \\
\hline 2000 & $\begin{array}{r}-0.0964 \\
(-0.0179)\end{array}$ & $\begin{array}{r}-0.0823 \\
(0.0000)\end{array}$ & $\begin{array}{r}-0.2332 \\
(-0.1463)\end{array}$ & $\begin{array}{r}-0.1254 \\
(-0.0609)\end{array}$ & $\begin{array}{c}0.1369 * \\
(0.1284)\end{array}$ & $\begin{array}{r}0.0431 \\
(0.0609)\end{array}$ \\
\hline 2001 & $\begin{array}{r}-0.0433 \\
(0.0000)\end{array}$ & $\begin{array}{r}-0.0116 \\
(0.0010)\end{array}$ & $\begin{array}{r}-0.2260 \\
(-0.2912)\end{array}$ & $\begin{array}{r}-0.1908 \\
(-0.2193)\end{array}$ & $\begin{array}{c}0.1827^{\star \star} \\
(0.2912)^{\star \star \star}\end{array}$ & $\begin{array}{c}0.1792 \text { ** } \\
(0.2203)^{* \star \star}\end{array}$ \\
\hline 2002 & $\begin{array}{r}-0.0601 \\
(0.0000)\end{array}$ & $\begin{array}{r}-0.0500 \\
(0.0000)\end{array}$ & $\begin{array}{r}-0.2536 \\
(-0.2152)\end{array}$ & $\begin{array}{r}-0.2146 \\
(-0.1466)\end{array}$ & $\begin{array}{c}0.1935^{\star \star} \\
(0.2152)^{\star \star \star}\end{array}$ & $\begin{array}{c}0.1646 \text { * } \\
(0.1466) * *\end{array}$ \\
\hline 2003 & $\begin{array}{r}-0.0170 \\
(0.0000)\end{array}$ & $\begin{array}{r}-0.0155 \\
(0.0000)\end{array}$ & $\begin{array}{r}-0.2446 \\
(-0.2567)\end{array}$ & $\begin{array}{r}-0.2311 \\
(-0.2623)\end{array}$ & $\begin{array}{r}0.2276 \text { *** } \\
(0.2567)^{\star \star \star}\end{array}$ & $\begin{array}{c}0.2156 \text { ** } \\
(0.2623)^{* * *}\end{array}$ \\
\hline 2004 & $\begin{array}{r}-0.0501 \\
(-0.0031)\end{array}$ & $\begin{array}{l}-0.0311 \\
(0.0000)\end{array}$ & $\begin{array}{r}-0.2193 \\
(-0.2447)\end{array}$ & $\begin{array}{r}-0.1791 \\
(-0.2129)\end{array}$ & $\begin{array}{c}0.1692^{\star \star} \\
(0.2416)^{\star \star \star}\end{array}$ & $\begin{array}{c}0.1480 \text { * } \\
(0.2129)^{* *}\end{array}$ \\
\hline
\end{tabular}

This table reports the mean and median values (in parentheses) of the sales- and asset-based excess value measure for focused and diversified firms and each calendar year in the sample. All firms reporting more 
than one segment (with differing SIC or NAICS) codes are classified as diversified. The equality of means is tested using a standard $t$-test and the equality of medians using a non-parametric Mann-Whitney test. $* * * / * * / *$ denotes statistical significance at the $1 \% / 5 \% / 10 \%$ level. 
Table 4: Mean and median excess value for various degrees of diversification

\begin{tabular}{|c|c|c|c|c|c|c|}
\hline \multicolumn{7}{|c|}{ Panel A: Number of Segments } \\
\hline & & 1 & 2 & 3 & 4 & $\geq 5$ \\
\hline \multirow{3}{*}{$\begin{array}{l}\text { Excess Value } \\
\text { (Sales) }\end{array}$} & Mean & -0.0300 & -0.1891 & -0.1776 & -0.2047 & -0.1851 \\
\hline & Median & 0.0000 & -0.2023 & -0.1904 & -0.2119 & -0.2748 \\
\hline & Obs. & 2417 & 795 & 486 & 222 & 140 \\
\hline \multirow{3}{*}{$\begin{array}{l}\text { Excess Value } \\
\text { (Assets) }\end{array}$} & Mean & -0.0251 & -0.1709 & -0.1707 & -0.1768 & -0.1973 \\
\hline & Median & 0.0000 & -0.1832 & -0.2013 & -0.2296 & -0.2432 \\
\hline & Obs. & 2339 & 668 & 452 & 220 & 133 \\
\hline \multirow{3}{*}{$\begin{array}{l}\text { Excess Value } \\
\text { (Hybrid) }\end{array}$} & Mean & -0.0226 & -0.1643 & -0.1768 & -0.1904 & -0.1452 \\
\hline & Median & 0.0000 & -0.1824 & -0.1867 & -0.2054 & -0.2373 \\
\hline & Obs. & 2439 & 795 & 488 & 221 & 139 \\
\hline \multicolumn{7}{|c|}{ Panel B: Sales-based Herfindahl-Hirshman Index (HS) } \\
\hline & & 1 & $0.8 \leq H S<1$ & $0.6 \leq H S<0.8$ & $0.4 \leq H S<0.6$ & $H S<0.4$ \\
\hline \multirow{3}{*}{$\begin{array}{l}\text { Excess Value } \\
\text { (Sales) }\end{array}$} & Mean & -0.0304 & -0.2087 & -0.1526 & -0.1776 & -0.2040 \\
\hline & Median & 0.0000 & -0.2281 & -0.1623 & -0.1902 & -0.2636 \\
\hline & Obs. & 2420 & 490 & 405 & 539 & 164 \\
\hline \multicolumn{7}{|c|}{ Panel C: Asset-based Herfindahl-Hirshman Index (HA) } \\
\hline & & 1 & $0.8 \leq H A<1$ & $0.6 \leq H A<0.8$ & $0.4 \leq H A<0.6$ & $H A<0.4$ \\
\hline \multirow{3}{*}{$\begin{array}{l}\text { Excess Value } \\
\text { (Assets) }\end{array}$} & Mean & -0.0248 & -0.1348 & -0.1776 & -0.1771 & -0.2636 \\
\hline & Median & 0.0000 & -0.1446 & -0.2116 & -0.1834 & -0.2817 \\
\hline & Obs. & 2344 & 432 & 367 & 499 & 151 \\
\hline
\end{tabular}

This table reports mean and median values of the excess value measures based on sales and assets, and the hybrid excess value measure for different numbers of segments (Panel A) and for various values of the Herfindahl-Hirshman indices (Panels B and C). 
Table 5: Pooled cross-sectional time series regressions of the sales-, asset-based excess value measures

\begin{tabular}{|c|c|c|c|c|c|c|c|c|c|}
\hline \multirow[t]{2}{*}{ Dependent Variable } & \multicolumn{3}{|c|}{ Excess Value (Sales) } & \multicolumn{3}{|c|}{ Excess Value (Assets) } & \multicolumn{3}{|c|}{ Excess Value (Hybrid) } \\
\hline & $(1)$ & $(2)$ & (3) & (4) & $(5)$ & (6) & (7) & (8) & (9) \\
\hline Intercept & $\begin{array}{l}-0.247^{\text {***}} \\
(0.090)\end{array}$ & $\begin{array}{l}-0.181 \text { ** } \\
(0.088)\end{array}$ & $\begin{array}{l}-0.701 \text { *** } \\
(0.140)\end{array}$ & $\begin{array}{l}0.359 * * * \\
(0.087)\end{array}$ & $\begin{array}{l}0.4111^{* * *} \\
(0.088)\end{array}$ & $\begin{array}{l}-0.086 \\
(0.139)\end{array}$ & $\begin{array}{l}-0.212^{\star \star} \\
(0.087)\end{array}$ & $\begin{array}{l}-0.147^{*} \\
(0.085)\end{array}$ & $\begin{array}{l}-0.630^{\star * \star} \\
(0.139)\end{array}$ \\
\hline Diversified & $\begin{array}{l}-0.244 \text { *** } \\
(0.038)\end{array}$ & & & $\begin{array}{l}-0.161 \text { *** } \\
(0.037)\end{array}$ & & & $\begin{array}{l}-0.234^{\star \star \star} \\
(0.037)\end{array}$ & & \\
\hline Number of Segments & & $\begin{array}{l}-0.094 \text { *** } \\
(0.024)\end{array}$ & & & $\begin{array}{l}-0.056 \text { *** } \\
(0.019)\end{array}$ & & & $\begin{array}{l}-0.088^{\star \star *} \\
(0.023)\end{array}$ & \\
\hline Herfindahl (Sales) & & & $\begin{array}{l}0.450 \text { *** } \\
(0.096)\end{array}$ & & & & & & $\begin{array}{l}0.424^{\text {** }} \\
(0.095)\end{array}$ \\
\hline Herfindahl (Assets) & & & & & & $\begin{array}{l}0.438^{* * *} \\
(0.095)\end{array}$ & & & \\
\hline In(Assets) & $\begin{array}{l}0.090^{* \star *} \\
(0.013)\end{array}$ & $\begin{array}{l}0.093^{* * *} \\
(0.013)\end{array}$ & $\begin{array}{l}0.086^{* * *} \\
(0.013)\end{array}$ & $\begin{array}{r}0.018 \\
(0.011)\end{array}$ & $\begin{array}{r}0.018 \\
(0.011)\end{array}$ & $\begin{array}{c}0.019 * \\
(0.011)\end{array}$ & $\begin{array}{l}0.085^{\star \star \star} \\
(0.013)\end{array}$ & $\begin{array}{l}0.087^{\star * \star} \\
(0.013)\end{array}$ & $\begin{array}{l}0.081^{\star * \star} \\
(0.013)\end{array}$ \\
\hline Leverage & $\begin{array}{l}-0.552 \text { *** } \\
(0.095)\end{array}$ & $\begin{array}{l}-0.582^{\text {*** }} \\
(0.098)\end{array}$ & $\begin{array}{l}-0.559 \text { *** } \\
(0.097)\end{array}$ & $\begin{array}{l}-0.693 \\
(0.105)\end{array}$ & $\begin{array}{l}-0.714^{\text {*** }} \\
(0.107)\end{array}$ & $\begin{array}{l}-0.701 \text { *** } \\
(0.105)\end{array}$ & $\begin{array}{l}-0.542^{\star \star \star} \\
(0.088)\end{array}$ & $\begin{array}{l}-0.568^{\star * *} \\
(0.091)\end{array}$ & $\begin{array}{l}-0.561^{\star \star \star} \\
(0.092)\end{array}$ \\
\hline R-squared & 0.090 & 0.0825 & 0.0758 & 0.104 & 0.099 & 0.110 & 0.084 & 0.076 & 0.071 \\
\hline F-test & $\begin{array}{l}29.990 * * * \\
(0.000)\end{array}$ & $\begin{array}{l}25.33^{\text {*** }} \\
(0.000)\end{array}$ & $\begin{array}{l}23.89 * * * \\
(0.000)\end{array}$ & $\begin{array}{l}22.290 * * * \\
(0.000)\end{array}$ & $\begin{array}{l}19.930 * * * \\
(0.000)\end{array}$ & $\begin{array}{l}24.250 * * * \\
(0.000)\end{array}$ & $\begin{array}{l}29.390^{\star \star \star} \\
(0.000)\end{array}$ & $\begin{array}{l}24.670^{\star * *} \\
(0.000)\end{array}$ & $\begin{array}{l}23.540 \text { *** } \\
(0.000)\end{array}$ \\
\hline Clusters & 664 & 664 & 664 & 669 & 669 & 669 & 671 & 671 & 670 \\
\hline $\mathrm{N}$ & 4054 & 4054 & 4012 & 3907 & 3907 & 3889 & 4076 & 4076 & 4029 \\
\hline
\end{tabular}

This table reports estimates from pooled cross-sectional time series regressions of the excess value measure based on sales (Panel A), assets (Panel $\mathrm{B}$ ), and both (Panel C) on different measures of diversification and control variables. We include the following explanatory variables: a dummy variable whether the firm reports more than one segment on Compustat's Segments tape (Diversified), the number of reported segments (Number of Segments), a sales- and an asset-based Herfindahl-Hirshman index (HHI) computed as the sum of the squares of each segment's sales (assets) as a proportion of total sales (assets) for the firm (Herfindahl (Sales) and Herfindahl (Assets)), the natural logarithm of total assets (ln(Assets)), and book leverage (Leverage). The standard errors (in parentheses) are based on the cluster-robust variant of the Huber-White sandwich estimator, which accounts for the dependence of observations within clusters (different year-observations for one specific firm). An $F$-test is performed for the simultaneous significance of all coefficients (except the constant). ***/**/* denotes statistical significance at the 1\%/5\%/10\% level. 
Table 6: Fixed effects regressions and Heckman's self selection model of the sales-based excess value measure

\begin{tabular}{|c|c|c|c|c|c|c|}
\hline \multicolumn{7}{|c|}{ Dependent Variable: Excess Value based on Sales } \\
\hline & \multicolumn{3}{|c|}{ Panel A: Fixed effects regressions } & & \multicolumn{2}{|c|}{ Panel B: Heckman selection model } \\
\hline & (1) & $(2)$ & (3) & & $(4)$ & $(5)$ \\
\hline Intercept & $\begin{array}{l}0.265^{* * *} \\
(0.077)\end{array}$ & $\begin{array}{l}0.352^{\text {*** }} \\
(0.077)\end{array}$ & $\begin{array}{r}0.023 \\
(0.102)\end{array}$ & Intercept & $\begin{array}{l}-0.413^{* *} \\
(0.182)\end{array}$ & $\begin{array}{l}-0.234 \text { * } \\
(0.135)\end{array}$ \\
\hline Diversified & $\begin{array}{l}-0.154^{* * *} \\
(0.023)\end{array}$ & & & Diversified & $\begin{array}{l}-0.238^{* * *} \\
(0.039)\end{array}$ & $\begin{array}{l}-0.250 \text { *** } \\
(0.038)\end{array}$ \\
\hline Number of Segments & & $\begin{array}{l}-0.049 \text { *** } \\
(0.011)\end{array}$ & & Lambda & $\begin{array}{r}0.064 \\
(0.055)\end{array}$ & $\begin{array}{l}-0.004 \\
(0.032)\end{array}$ \\
\hline Herfindahl (Sales) & & & $\begin{array}{l}0.291 \text { *** } \\
(0.061)\end{array}$ & In(Assets) & $\begin{array}{l}0.102 \text { *** } \\
(0.017)\end{array}$ & $\begin{array}{l}0.090^{* * \star} \\
(0.013)\end{array}$ \\
\hline In(Assets) & $\begin{array}{r}0.012 \\
(0.010)\end{array}$ & $\begin{array}{r}0.003 \\
(0.010)\end{array}$ & $\begin{array}{r}0.002 \\
(0.010)\end{array}$ & Leverage & $\begin{array}{l}-0.539 * * * \\
(0.098)\end{array}$ & $\begin{array}{l}-0.554 \text { *** } \\
(0.096)\end{array}$ \\
\hline Leverage & $\begin{array}{l}-0.528 \text { *** } \\
(0.069)\end{array}$ & $\begin{array}{l}-0.536 \text { *** } \\
(0.070)\end{array}$ & $\begin{array}{l}-0.526 \text { *** } \\
(0.070)\end{array}$ & & & \\
\hline R-squared within & 0.032 & 0.025 & 0.026 & Year dummy variables & Included & Included \\
\hline R-squared between & 0.035 & 0.025 & 0.020 & R-squared & 0.093 & 0.092 \\
\hline R-squared overall & 0.041 & 0.027 & 0.024 & F-test & $23.410 * \star \star$ & $23.080 * \star \star$ \\
\hline \multirow[t]{2}{*}{ F-test } & $36.810 * \star \star$ & $28.790 * \star \star$ & $29.900 * \star \star$ & & $(0.000)$ & $(0.000)$ \\
\hline & $(0.000)$ & $(0.000)$ & $(0.000)$ & Clusters & 657 & 657 \\
\hline N & 4054 & 4054 & 4012 & $\mathrm{~N}$ & 3987 & 3987 \\
\hline
\end{tabular}

This table reports estimates from fixed effects regressions (Panel A) and Heckman (1979)'s self-selection model (Panel B) for the excess value measure based on sales. We include the following explanatory variables in the regression equations (second-stage regression in Panel B): a dummy variable whether the firm reports more than one segment on Compustat's Segments tape (Diversified), the number of reported segments (Number of Segments), a sales-based Herfindahl-Hirshman index (HHI) computed as the sum of the squares of each segment's sales as a proportion of total sales for the firm (Herfindahl (Sales)), the natural logarithm of total assets (ln(Assets)), and book leverage (Leverage). In Panel B, the selection variable in the first-stage regression is a dummy variable whether the firm is diversified (Column 4) or a dummy variable whether the firm diversifies, i.e., increases the number of segments (Column 5). The first-stage regression (not reported) includes the following explanatory variables: the log of total assets, leverage, a dummy variable whether the firm pays a dividend, return on assets, dummy variables whether the firm belongs to the S\&P500 index and whether it is listed at NYSE, the fraction of diversified firms and the fraction of sales accounted for 
by diversified firms in the industry, median industry $\mathrm{Q}$ and its lagged value, the number of M\&A transactions in a given year (financial sector only) and the annual value of completed deals, and GDP growth and its lagged value. Lambda is the self-selection parameter. The standard errors (in parentheses) are based on the Huber-White sandwich estimator. An F-test is performed for the simultaneous significance of all coefficients (except the constant). ${ }^{* * * / * * * *}$ denotes statistical significance at the $1 \% / 5 \% / 10 \%$ level. 
Table 7: The valuation effect of related and unrelated diversification and interaction terms between diversification and firm characteristics

\begin{tabular}{|c|c|c|c|c|c|c|c|}
\hline \multicolumn{8}{|c|}{ Dependent Variable: Excess Value based on Sales } \\
\hline & \multicolumn{3}{|c|}{ Panel A: Interaction terms } & & \multicolumn{3}{|c|}{ Panel B: Related and unrelated diversification } \\
\hline & (1) & (2) & (3) & & (4) & (5) & (6) \\
\hline Intercept & $\begin{array}{l}-0.365 \text { *** } \\
(0.095)\end{array}$ & $\begin{array}{l}-0.403 \text { *** } \\
(0.106)\end{array}$ & $\begin{array}{l}-0.404 \text { *** } \\
(0.106)\end{array}$ & Intercept & $\begin{array}{r}-0.153 \\
(0.094)\end{array}$ & $\begin{array}{l}-0.205^{* *} \\
(0.094)\end{array}$ & $\begin{array}{r}-0.131 \\
(0.094)\end{array}$ \\
\hline Diversified & $\begin{array}{r}0.177 \\
(0.153)\end{array}$ & $\begin{array}{r}0.085 \\
(0.158)\end{array}$ & $\begin{array}{r}0.175 \\
(0.159)\end{array}$ & Diversified (related) & $\begin{array}{l}-0.178 \text { *** } \\
(0.056)\end{array}$ & & \\
\hline Diversified*Leverage & $\begin{array}{l}-0.569 * * * \\
(0.201)\end{array}$ & & & Diversified (unrelated) & & $\begin{array}{l}-0.181 \text { *** } \\
(0.045)\end{array}$ & \\
\hline Diversified*In(Assets) & & $\begin{array}{l}-0.045^{* *} \\
(0.021)\end{array}$ & $\begin{array}{l}-0.058^{* * \star} \\
(0.022)\end{array}$ & Non-financial Segment & & & $\begin{array}{l}-0.215^{* *} \\
(0.084)\end{array}$ \\
\hline DiversifiedTBTF & & & $\begin{array}{l}0.024 \text { ** } \\
(0.011)\end{array}$ & In(Assets) & $\begin{array}{l}0.068^{* * *} \\
(0.013)\end{array}$ & $\begin{array}{l}0.079 \text { *** } \\
(0.013)\end{array}$ & $\begin{array}{l}0.064^{* * *} \\
(0.013)\end{array}$ \\
\hline In(Assets) & $\begin{array}{l}0.096^{* * *} \\
(0.013)\end{array}$ & $\begin{array}{l}0.115^{\text {*** }} \\
(0.016)\end{array}$ & $\begin{array}{l}0.115^{* \star *} \\
(0.016)\end{array}$ & Leverage & $\begin{array}{l}-0.573^{\star * \star} \\
(0.097)\end{array}$ & $\begin{array}{l}-0.574 \text { *** } \\
(0.097)\end{array}$ & $\begin{array}{l}-0.579 * * * \\
(0.097)\end{array}$ \\
\hline Leverage & $\begin{array}{l}-0.440 \text { *** } \\
(0.101)\end{array}$ & $\begin{array}{l}-0.568 \text { *** } \\
(0.096)\end{array}$ & $\begin{array}{l}-0.565^{* \star *} \\
(0.095)\end{array}$ & & & & \\
\hline R-squared & 0.097 & 0.094 & 0.097 & R-squared & 0.061 & 0.070 & 0.059 \\
\hline F-test & $\begin{array}{l}24.480 \text { *** } \\
(0.000)\end{array}$ & $\begin{array}{l}24.510^{\text {*** }} \\
(0.000)\end{array}$ & $\begin{array}{l}20.960 \text { *** } \\
(0.000)\end{array}$ & Wald & $\begin{array}{l}17.600 \text { *** } \\
(0.000)\end{array}$ & $\begin{array}{l}20.790 \text { *** } \\
(0.000)\end{array}$ & $\begin{array}{l}17.470 \text { *** } \\
(0.000)\end{array}$ \\
\hline Clusters & 664 & 664 & 664 & Clusters & 664 & 664 & 664 \\
\hline $\mathrm{N}$ & 4054 & 4054 & 4054 & $\mathrm{~N}$ & 4054 & 4054 & 4054 \\
\hline
\end{tabular}

Panel A reports estimates from pooled cross-sectional time series regressions of the excess value measure based on sales on a dummy variable whether the firm is diversified and interaction terms between the diversification dummy variable and different firm characteristics. The explanatory variables are defined as follows: a dummy variable whether the firm reports more than one segment on Compustat's Segments tape (Diversified), an interaction term between the dummy variable whether the firm is diversified and book leverage (Diversified*Leverage), an interaction term between the dummy variable whether the firm is diversified and the natural logarithm of total assets (Diversified*In(Assets)), an interaction term between the diversification dummy variable and a dummy variable whether the firm has total assets above \$100bn to capture the largest financial companies which possibly benefit from so-called “too big to fail” guarantees (Diversified*TBTF), the natural logarithm of total assets (ln(Assets)), 
and book leverage (Leverage). Panel B reports estimates from pooled cross-sectional time series regressions of the excess value measure based on sales on different measures of related and unrelated diversification and control variables. The explanatory variables are defined as follows: A dummy variable which is equal to one if a firm is diversified at the five- digit level for NAICS codes or the four-digit-level for SIC codes (Diversified (related)), a dummy variable which is equal to one if a firm is diversified at the three-digit level for NAICS codes or at the two-digit-level for SIC codes (Diversified (unrelated)), a dummy variable which is equal to one if a firm has at least one segment outside the financial services sector (Non-financial segment), the natural logarithm of total assets (ln(Assets)), and book leverage (Leverage). The standard errors (in parentheses) are based on the cluster-robust variant of the Huber-White sandwich estimator, which accounts for the dependence of observations within clusters (different year-observations for one specific firm). An F-test is performed for the simultaneous significance of all coefficients (except the constant). $* * * / * * / *$ denotes statistical significance at the $1 \% / 5 \% / 10 \%$ level 
Table 8: Sample overview on diversifying and focusing firms (1986-2004)

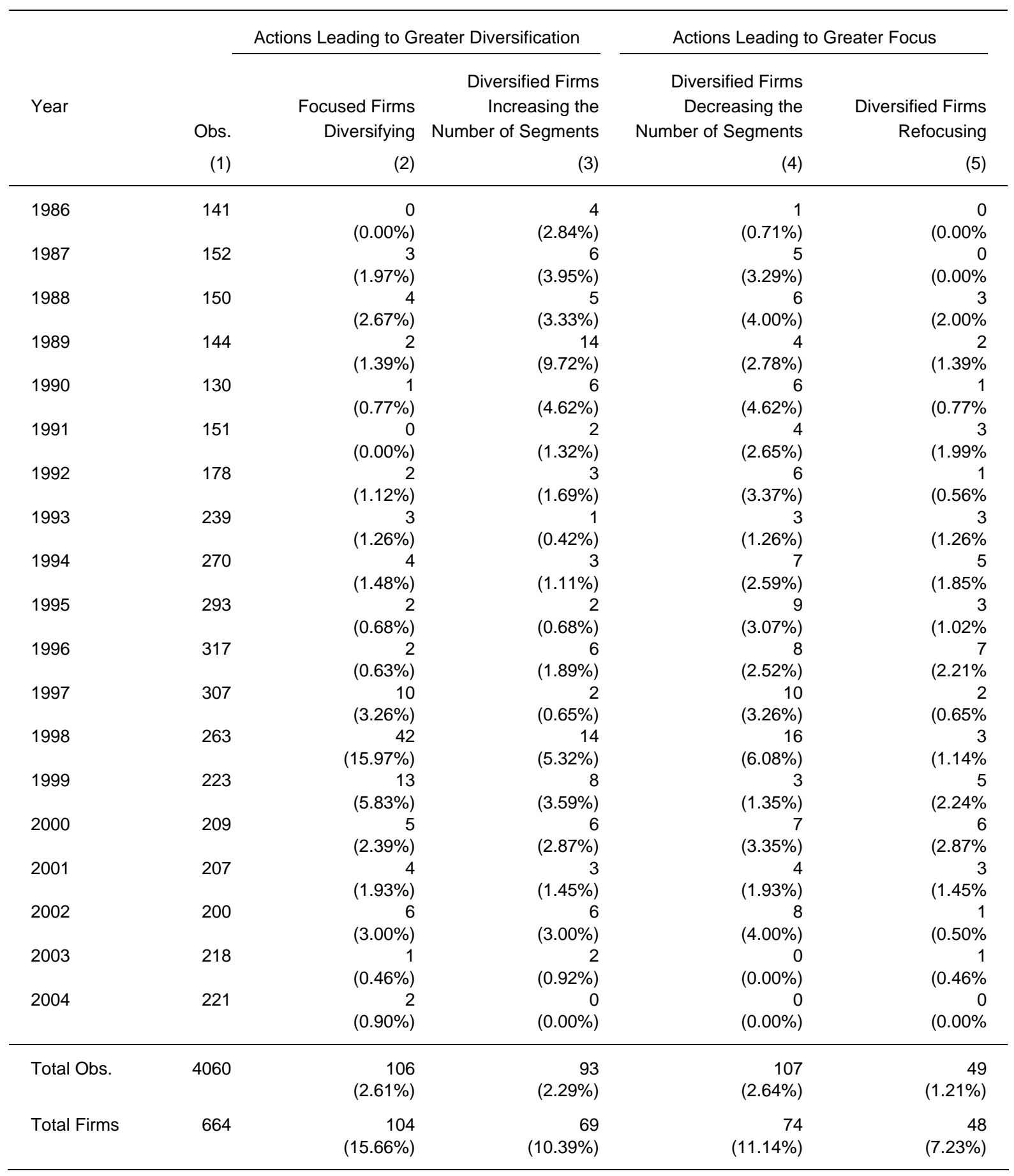

This table reports the number of previously focused firms diversifying (Column 2), diversified firms increasing the number of segments (Column 3), diversified firms decreasing the number of segments (Column 4), and previously diversified firms refocusing (Column 5) for each calendar year in the sample. Column 1 reports the number of total observations in the sample for each year. The percentage of observations belonging to each of the four different groups in each sample year are in parentheses. 
Table 9: The valuation effect of changes in diversification and focus

\begin{tabular}{|c|c|c|c|c|}
\hline \multicolumn{5}{|c|}{ Panel A: Descriptive Statistics } \\
\hline & Excess Value & Excess Value $(t-1)$ & Excess Value $(t-2)$ & Excess Value $(t-3)$ \\
\hline & $(1)$ & (2) & (3) & (4) \\
\hline \multicolumn{5}{|c|}{ Previously focused firms diversifying } \\
\hline Mean & -0.100 & 0.029 & 0.050 & 0.019 \\
\hline Median & -0.113 & 0.000 & 0.018 & -0.005 \\
\hline Obs. & 106 & 105 & 90 & 73 \\
\hline \multicolumn{5}{|c|}{ Diversified firms increasing the number of segments } \\
\hline Mean & -0.100 & -0.009 & -0.125 & -0.085 \\
\hline Median & -0.187 & -0.060 & -0.172 & -0.220 \\
\hline Obs. & 93 & 93 & 74 & 72 \\
\hline \multicolumn{5}{|c|}{ Diversified firms decreasing the number of segments } \\
\hline Mean & -0.146 & -0.213 & -0.187 & -0.249 \\
\hline Median & -0.140 & -0.237 & -0.209 & -0.218 \\
\hline Obs. & 107 & 107 & 95 & 87 \\
\hline \multicolumn{5}{|c|}{ Previously diversified firms focusing } \\
\hline Mean & -0.156 & -0.321 & -0.244 & -0.287 \\
\hline Median & -0.236 & -0.324 & -0.255 & -0.274 \\
\hline Obs. & 49 & 49 & 44 & 37 \\
\hline
\end{tabular}

Panel B: Univariate Regressions of $\Delta$ Excess Value

\begin{tabular}{lcrrr} 
& $\begin{array}{r}\text { Focused Firms } \\
\text { Diversifying }\end{array}$ & $\begin{array}{r}\text { Diversified Firms } \\
\text { Diversifying }\end{array}$ & $\begin{array}{r}\text { Diversified Firms } \\
\text { Focusing }\end{array}$ & $\begin{array}{r}\text { Diversified Firms } \\
\text { becoming Focused }\end{array}$ \\
\hline Intercept & $-0.011^{*}$ & $-0.012^{* *}$ & $-0.017^{* * *}$ & $-0.017^{* * *}$ \\
& $(0.078)$ & $(0.045)$ & $(0.006)$ & $(0.004)$ \\
Coefficient & $-0.124^{* *}$ & $-0.078^{*}$ & $0.084^{* *}$ & $0.182^{* *}$ \\
& $(0.016)$ & $(0.060)$ & $(0.045)$ & $(0.016)$ \\
R-squared & 0.002 & 0.001 & 0.001 & 0.003 \\
Clusters & 574 & 574 & 574 & 574 \\
Obs. & 3420 & 3420 & 3420 & 3420 \\
\hline
\end{tabular}

Panel A of this table reports mean and median values of the sales-based excess value measure for years $t, t-1, t-2$, and $t-3$ for previously focused firms diversifying in year $t$, diversified firms increasing the number of segments in year $t$, diversified firms decreasing the number of segments in year $t$, and previously diversified firms refocusing in year $t$. Panel B reports the results of univariate OLS regressions of the change in excess value between years $t$ and $t-1$ on a dummy variable, which is equal to one if a previously focused firm diversifies (Column 1), a diversified firm increases the number of segments (Column 2), a diversified firm decreases the number of segments (Column 3), and a previously diversified firm refocuses (Column 4). The numbers in parentheses are $p$-values for two-sided tests. $* * * / * * / *$ denotes statistical significance at the $1 \% / 5 \% / 10 \%$ level. 
Table 10: Sample overview on geographic diversification by calendar year

\begin{tabular}{rrrrrr}
\hline Year & Focused & Focused (\%) & Diversified & Diversified (\%) & N \\
\hline 1985 & 14 & $29.79 \%$ & 33 & $70.21 \%$ & 47 \\
1986 & 23 & $16.31 \%$ & 118 & $83.69 \%$ & 141 \\
1987 & 30 & $19.74 \%$ & 122 & $80.26 \%$ & 152 \\
1988 & 29 & $19.33 \%$ & 121 & $80.67 \%$ & 150 \\
1989 & 32 & $22.22 \%$ & 112 & $77.78 \%$ & 144 \\
1990 & 29 & $22.31 \%$ & 101 & $77.69 \%$ & 130 \\
1991 & 31 & $20.53 \%$ & 120 & $79.47 \%$ & 151 \\
1992 & 33 & $18.54 \%$ & 145 & $81.46 \%$ & 178 \\
1993 & 44 & $18.41 \%$ & 195 & $81.59 \%$ & 239 \\
1994 & 50 & $18.52 \%$ & 220 & $81.48 \%$ & 270 \\
1995 & 51 & $17.41 \%$ & 242 & $82.59 \%$ & 293 \\
1996 & 54 & $17.03 \%$ & 263 & $82.97 \%$ & 317 \\
1997 & 56 & $18.42 \%$ & 248 & $81.58 \%$ & 304 \\
1998 & 111 & $43.36 \%$ & 145 & $56.64 \%$ & 256 \\
1999 & 107 & $76.43 \%$ & 33 & $23.57 \%$ & 140 \\
2000 & 106 & $79.10 \%$ & 28 & $20.90 \%$ & 134 \\
2001 & 103 & $75.18 \%$ & 34 & $24.82 \%$ & 137 \\
2002 & 98 & $75.38 \%$ & 32 & $24.62 \%$ & 130 \\
2003 & 98 & $74.81 \%$ & 33 & $25.19 \%$ & 131 \\
2004 & 98 & $72.59 \%$ & 37 & $27.41 \%$ & 135 \\
Sum & 1197 & & 2382 & & 3579 \\
\hline
\end{tabular}

This table reports the number and percentage of geographically focused firms in the sample, the number and percentage of geographically diversified firms in the sample, and the number of total observations $(N)$ in this section for each sample calendar year. All firms reporting more than one geographic segment in Compustat's Segment Files are classified as geographically diversified. 
Table 11: Pooled cross-sectional time series regressions including variables for geographic diversification

\begin{tabular}{|c|c|c|c|c|c|c|c|}
\hline & \multicolumn{7}{|c|}{ Dependent Variable: Excess Value based on Sales } \\
\hline & \multicolumn{5}{|c|}{ All Firm-Years } & \multirow{2}{*}{$\frac{\text { Funct. Foc. Firm-Years }}{(6)}$} & \multirow{2}{*}{$\frac{\text { Funct. Div. Firm-Years }}{(7)}$} \\
\hline & $(1)$ & $(2)$ & (3) & (4) & $(5)$ & & \\
\hline \multirow[t]{2}{*}{ Intercept } & $-0.289 * * *$ & -0.356 *** & $-0.375^{\star \star \star}$ & $-0.375^{\star \star *}$ & $-0.269 * *$ & $-0.473 * * *$ & -0.183 \\
\hline & $(0.101)$ & $(0.129)$ & $(0.141)$ & $(0.141)$ & $(0.104)$ & $(0.118)$ & $(0.169)$ \\
\hline \multirow[t]{2}{*}{ Functionally Diversified } & $-0.242 * \star \star$ & $-0.243 * \star \star$ & $-0.241^{\star \star \star}$ & $-0.237^{\star \star \star}$ & $-0.285^{\star \star \star}$ & & \\
\hline & $(0.039)$ & $(0.039)$ & $(0.039)$ & $(0.039)$ & $(0.055)$ & & \\
\hline \multirow[t]{2}{*}{ Geographically Diversified } & 0.058 & 0.156 & 0.182 & 0.236 & 0.030 & 0.035 & 0.093 * \\
\hline & $(0.035)$ & $(0.117)$ & $(0.144)$ & $(0.148)$ & $(0.044)$ & $(0.044)$ & $(0.052)$ \\
\hline \multirow[t]{2}{*}{ Funct. DivGeo. Div } & & & & & 0.067 & & \\
\hline & & & & & $(0.065)$ & & \\
\hline \multirow[t]{2}{*}{ Diversified*Leverage } & & -0.136 & & & & & \\
\hline & & $(0.156)$ & & & & & \\
\hline \multirow[t]{2}{*}{ Diversified*In(Assets) } & & & -0.017 & -0.026 & & & \\
\hline & & & $(0.019)$ & $(0.020)$ & & & \\
\hline \multirow[t]{2}{*}{ DiversifiedTBTF } & & & & $0.217^{*}$ & & & \\
\hline & & & & $(0.125)$ & & & \\
\hline \multirow[t]{2}{*}{ In(Assets) } & $0.094 * * *$ & 0.094 *** & $0.106^{\star \star \star}$ & $0.105^{\star \star \star}$ & $0.093^{\star \star *}$ & $0.117^{\star \star \star *}$ & 0.083 *** \\
\hline & $(0.014)$ & $(0.014)$ & $(0.019)$ & $(0.019)$ & $(0.014)$ & $(0.017)$ & $(0.020)$ \\
\hline \multirow[t]{2}{*}{ Leverage } & $-0.574 * \star \star$ & -0.482 *** & $-0.573^{\star \star \star}$ & 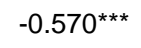 & $-0.570 * \star \star$ & -0.502 *** & $-0.930 * \star *$ \\
\hline & $(0.102)$ & $(0.149)$ & $(0.103)$ & $(0.103)$ & $(0.102)$ & $(0.112)$ & $(0.224)$ \\
\hline R-squared & 0.094 & 0.095 & 0.095 & 0.097 & 0.095 & 0.087 & 0.090 \\
\hline \multirow[t]{2}{*}{ F-test } & $21.400 * * *$ & 17.580 *** & $17.340^{\star \star \star}$ & $15.930^{\star \star *}$ & $17.810^{\star \star *}$ & $17.810^{* \star *}$ & $8.780 * \star *$ \\
\hline & $(0.000)$ & $(0.000)$ & $(0.000)$ & $(0.000)$ & $(0.000)$ & $(0.000)$ & $(0.000)$ \\
\hline Clusters & 620 & 620 & 620 & 620 & 620 & 474 & 280 \\
\hline $\mathrm{N}$ & 3574 & 3574 & 3574 & 3574 & 3574 & 2179 & 1395 \\
\hline
\end{tabular}

This table reports estimates from pooled cross-sectional time series regressions of the excess value measure based on sales on dummy variables whether a firm is functionally and geographically diversified, interaction terms between the geographical diversification variable and firm characteristics, and control variables. Columns 1 to 5 present the results from an analysis including all firm-year observations, Columns 6 and 7 for the sub-samples of functionally focused and functionally diversified firm-year observations, respectively. All firms reporting more than one segment (with differing SIC or NAICS) codes are classified as functionally diversified. All firms reporting at least one foreign segment are classified as geographically diversified. The explanatory variables are defined as follows: a dummy variable whether the firm reports more than one product segment on Compustat's Segments tape (Functionally Diversified), 
a dummy variable whether the firm reports more than one geographic segment on Compustat's Segments tape (Geographically Diversified), an interaction term between the functional and geographic diversification dummy variables (Funct. Div*Geo. Div), an interaction term between the dummy variable whether the firm is geographically diversified and book leverage (Diversified*Leverage), an interaction term between the dummy variable whether the firm is geographically diversified and the natural logarithm of total assets (Diversified*ln(Assets)), an interaction term between the geographic diversification dummy variable and a dummy variable whether the firm has total assets above $\$ 100 \mathrm{bn}$ to capture the largest financial companies which possibly benefit from so-called "too big to fail" guarantees (Diversified*TBTF), the natural logarithm of total assets (ln(Assets)), and book leverage (Leverage). The standard errors (in parentheses) are based on the cluster-robust variant of the Huber-White sandwich estimator, which accounts for the dependence of observations within clusters (different year-observations for one specific firm). An F-test is performed for the simultaneous significance of all coefficients (except the constant). $* * * / * * / *$ denotes statistical significance at the $1 \% / 5 \% / 10 \%$ level. 